\title{
Are Integrins Still Practicable Targets for Anti-Cancer Therapy?
}

\author{
Begoña Alday-Parejo ${ }^{1}$, Roger Stupp ${ }^{2}$ and Curzio Rüegg $1, * \mathbb{C}$ \\ 1 Pathology Unit, Department of Oncology, Microbiology and Immunology, Faculty of Science and Medicine, \\ University of Fribourg, Chemin du Musée 18, Per 17, CH-1700 Fribourg, Switzerland \\ 2 Departments of Neurological Surgery, Malnati Brain Tumor Institute of the Lurie Comprehensive Cancer \\ Center, Neurology and Medicine, Feinberg School of Medicine, Northwestern University, 676 N St Clair St, \\ Suite 2210, Chicago, IL 60611, USA \\ * Correspondence: curzio.ruegg@unifr.ch
}

Received: 1 June 2019; Accepted: 9 July 2019; Published: 12 July 2019

check for updates

\begin{abstract}
Correlative clinical evidence and experimental observations indicate that integrin adhesion receptors, in particular those of the $\alpha \mathrm{V}$ family, are relevant to cancer cell features, including proliferation, survival, migration, invasion, and metastasis. In addition, integrins promote events in the tumor microenvironment that are critical for tumor progression and metastasis, including tumor angiogenesis, matrix remodeling, and the recruitment of immune and inflammatory cells. In spite of compelling preclinical results demonstrating that the inhibition of integrin $\alpha \mathrm{V} \beta 3 / \alpha \mathrm{V} \beta 5$ and $\alpha 5 \beta 1$ has therapeutic potential, clinical trials with integrin inhibitors targeting those integrins have repeatedly failed to demonstrate therapeutic benefits in cancer patients. Here, we review emerging integrin functions and their proposed contribution to tumor progression, discuss preclinical evidence of therapeutic significance, revisit clinical trial results, and consider alternative approaches for their therapeutic targeting in oncology, including targeting integrins in the other cells of the tumor microenvironment, e.g., cancer-associated fibroblasts and immune/inflammatory cells. We conclude that integrins remain a valid target for cancer therapy; however, agents with better pharmacological properties, alternative models for their preclinical evaluation, and innovative combination strategies for clinical testing (e.g., together with immuno-oncology agents) are needed.
\end{abstract}

Keywords: cancer; angiogenesis; tumor microenvironment; imaging; therapy

\section{Introduction}

Since their initial discovery as extracellular matrix (ECM) cell adhesion receptors over 30 years ago, integrins were rapidly identified as molecules relevant to cancer cell functions, notably migration, invasion, and metastasis formation. Cancer and leukocyte biology research greatly contributed to unraveling many of the cellular and molecular features of integrins as we know them today $[1,2]$. The characterization of their molecular structure, activation, and signaling functions, lead to fundamental discoveries with far-reaching implications in many fields of biology and medicine $[3,4]$. The development of integrin inhibitors based on the Arg-Gly-Asp binding sequence, raised great hopes for the development of novel anti-cancer therapies, in particular to inhibit tumor angiogenesis [5]. Despite encouraging results in preclinical models, all efforts to translate the experimental results into a therapeutic benefit for cancer patients were disappointing, and can be illustrated by the failure of the $\alpha \mathrm{V} \beta 3 / \alpha \mathrm{V} \beta 5$ inhibitor cilengitide as an anti-cancer drug [6,7]. This integrin inhibitor has gone through a full preclinical and clinical development cycle, and ultimately failed in randomized trials in several disease entities. At this point, a fundamental question is warranted: are integrins still practicable therapeutic targets in cancer, despite the failure of targeting $\alpha \mathrm{V} \beta 3 / \alpha \mathrm{V} \beta 5$ and $\alpha 5 \beta 1$ in several clinical 
trials? We need to re-evaluate the role of integrins in cancer, including how can we best target them, and how we can translate preclinical observations into clinical benefits. Here, we will review selected aspects of integrin biology and cancer-related function, and discuss some considerations for future developments as anti-cancer therapeutics aiming at lessons learned.

\section{Integrin Adhesion Receptors, a Class of Its Own}

Integrins are $\alpha \beta$ heterodimeric cell surface adhesion receptors. There are $18 \alpha$ and eight $\beta$ subunits consisting each of a long extracellular domain (750-1000 amino acids), and short transmembrane and cytoplasmic domains (20-75 amino acids, except for the $\beta 4$ cytoplasmic subunit up to over 1000 amino acids long), which in combination form 24 different heterodimers [8,9]. Integrins bind to insoluble ECM proteins (e.g., fibronectins, laminins, collagens), matricellular proteins (e.g., Cyr61/CTGF/NOV, CCN), cell surface (e.g., Intercellular Adhesion Molecules, ICAMs; Vascular Cell Adhesion Molecule-1, VCAM-1) and soluble (e.g., fibrinogen, complement proteins, Vascular Endothelial Growth Factor, VEGF; Fibroblast Growth Factor 2, FGF2; angipoietin-1 or Transforming Growth Factor $\beta$, TGF $\beta$ ) $[9,10]$ ligands. Binding occurs through a pocket formed by the $\alpha$ and $\beta$ subunits or through the I-domain on some $\alpha$ chains [11]. The ligand binding specificity is promiscuous (one integrin binds multiple ligands) and redundant (different integrins bind to the same ligand) [12]. Promiscuity may be advantageous in conditions when function is more important than the specificity of the eliciting event. This is the case during wound healing, where cells have to cope with a rapidly changing ECM. Integrin $\alpha \mathrm{V} \beta 3$, which binds nearly a dozen of different ligands, is the prototype of a promiscuous integrin. Redundancy may reflect the need for a given cell to respond differently to the same ECM protein. For instance, $\alpha 5 \beta 1$ and $\alpha \mathrm{V} \beta 6$ bind to fibronectin, but elicit different responses [13]. Integrins exist in a low affinity, closed (bent) form and a high affinity, active, open (extended) form. Integrin activation involves the binding of two cytoplasmic adaptor proteins, talin and kindlin, to the intracellular domain of the $\beta$-integrin ("inside-out signaling"). In turn, high-affinity ligand binding induces a further conformational change of the cytoplasmic tails, promoting linkage to the actin cytoskeleton, focal complexes formation, and signaling events that are required for stable cell adhesion, spreading, migration, proliferation, survival, and differentiation [11,14]. Many integrins expressed on cancer cells or cells of the tumor microenvironment have been reported to be involved in cancer progression. An overview is given in Table 1.

Table 1. Overview of integrins expressed in cancer cells and the cells of the tumor microenvironment. The table lists the main integrins reported to play a role in cancer. For further reading, we refer to specific reviews and original articles [9,12,13,15-32]. Abbreviations: CAF, Cancer Associated Fibroblasts, MyF, Myofibroblasts.

\begin{tabular}{|c|c|c|c|c|c|}
\hline \multirow{2}{*}{$\begin{array}{c}\text { Integrin } \\
\text { Heterodimer }\end{array}$} & \multirow{2}{*}{$\begin{array}{l}\text { Arg-Gly-Asp } \\
\text { Ligand Binding } \\
\text { Dependency }\end{array}$} & \multicolumn{4}{|c|}{ Integrin Expression Patterns } \\
\hline & & Cancer Cells & Vascular Cells & CAF, MyF & Immune Cells \\
\hline$\alpha 1 \beta 1$ & & + & ++ & ++ & ++ \\
\hline$\alpha 2 \beta 1$ & & +++ & ++ & ++ & ++ \\
\hline$\alpha 3 \beta 1$ & & +++ & ++ & ++ & \\
\hline$\alpha 4 \beta 1$ & & +++ & & ++ & +++ \\
\hline$\alpha 5 \beta 1$ & + & +++ & +++ & ++ & ++ \\
\hline$\alpha 6 \beta 1$ & & +++ & ++ & & ++ \\
\hline$\alpha 7 \beta 1$ & & ++ & & & \\
\hline$\alpha 8 \beta 1$ & + & + & ++ & & \\
\hline$\alpha 9 \beta 1$ & & ++ & ++ & ++ & \\
\hline$\alpha 10 \beta 1$ & & ++ & & & \\
\hline$\alpha 11 \beta 1$ & & & & ++ & \\
\hline
\end{tabular}


Table 1. Cont.

\begin{tabular}{|c|c|c|c|c|c|}
\hline$\alpha \mathrm{V} \beta 1$ & + & ++ & ++ & ++ & \\
\hline$\alpha \mathrm{L} \beta 2$ & & & & & +++ \\
\hline$\alpha \mathrm{M} \beta 2$ & & & & & +++ \\
\hline$\alpha X \beta 2$ & & & & & +++ \\
\hline$\alpha \mathrm{D} \beta 2$ & & & & & +++ \\
\hline$\alpha \mathrm{V} \beta 3$ & + & +++ & +++ & ++ & +++ \\
\hline$\alpha \mathrm{iib} \beta 3$ & + & & & & Platelets \\
\hline$\alpha 6 \beta 4$ & & +++ & ++ & & \\
\hline$\alpha \mathrm{V} \beta 5$ & + & +++ & +++ & ++ & \\
\hline$\alpha \mathrm{V} \beta 6$ & + & +++ & & ++ & \\
\hline$\alpha 4 \beta 7$ & & & & + & +++ \\
\hline$\alpha \mathrm{E} \beta 7$ & & & & & +++ \\
\hline$\alpha \mathrm{V} \beta 8$ & + & ++ & +++ & ++ & ++ \\
\hline
\end{tabular}

\section{Integrin Adhesome as a Signaling Complex}

Integrins lack intrinsic enzymatic activity and rely on structural (e.g., paxillin, vinculin) and adaptor (e.g., SRC Homologous and Collagen-like (SHC), Crk-Associated Substrate, p130 (CAS)) proteins and enzymes (e.g., Focal Adhesion Kinase, FAK; Integrin Linked Kinase, ILK) for their signaling function. Many of the signaling pathways activated by integrins are also activated by growth factor receptors (GFRs), such as epidermal growth factor receptor (EGFR) or vascular growth factor receptor (VEGFR). Maximal signaling is achieved when GFRs and integrins are engaged. The molecular basis of this cooperation is believed to be the ability of engaged integrins to cluster intracellular adaptor and signaling proteins, thereby facilitating interactions with GFRs [33,34]. In addition, integrins can physically associate laterally with cell membrane proteins (e.g., CD151 or CD47) to elicit or modulate signaling events [35]. This complex and highly dynamic structure at the interface between cell adhesion and GFRs signaling is referred to as the adhesome [36]. Signaling integration provides enhanced specificity, as well as temporal and spatial control over many cellular events, compared to signaling from GFRs alone. Integrins activate four main signaling pathways relevant to cancer initiation, progression, metastasis, angiogenesis, and inflammation: the Rat Sarcoma (RAS)-mitogen activated protein kinases (MAPKs), the phosphoinositid-3-kinase (PI3K)-AKT, the Rho-family GTPases, and the Nuclear Factor kappa B (NF-KB) pathways (for more insights and details, we refer to recently published reviews [37-42].

\section{Cancer Cell Integrins}

Soon after their discovery, it was observed that integrin expression is altered in cancer compared to the corresponding healthy tissue, particularly of $\alpha 3 \beta 1, \alpha 4 \beta 1, \alpha 5 \beta 1, \alpha 6 \beta 4, \alpha \mathrm{v} \beta 3, \alpha \mathrm{v} \beta 5, \alpha \mathrm{v} \beta 6$, and $\alpha \mathrm{v} \beta 8$ [28], and that in certain cancers, this altered expression was correlated with outcomes [43]. The complexity of integrin regulation, ECM composition, concomitant signaling from GFRs, and pleiotropic functions, together with the possibility that their contribution to cancer may differ across different cancer types, stages, and treatment, significantly complicated assigning a specific cancer-related phenotype to a given integrin. Observations about their clinical relevance were merely correlative and often contradictory $[16,18,19,44]$. Nevertheless, some key contributions to cancer progression, in particular metastasis, have been established. For a general overview of cancer-related functions, in particular to the metastatic cascade, we refer to some recent comprehensive reviews $[13,20,23,28,30,37,45]$. Here, we will discuss selected known and emerging roles of integrins and their relevance to events critical for cancer progression (Figure 1). 


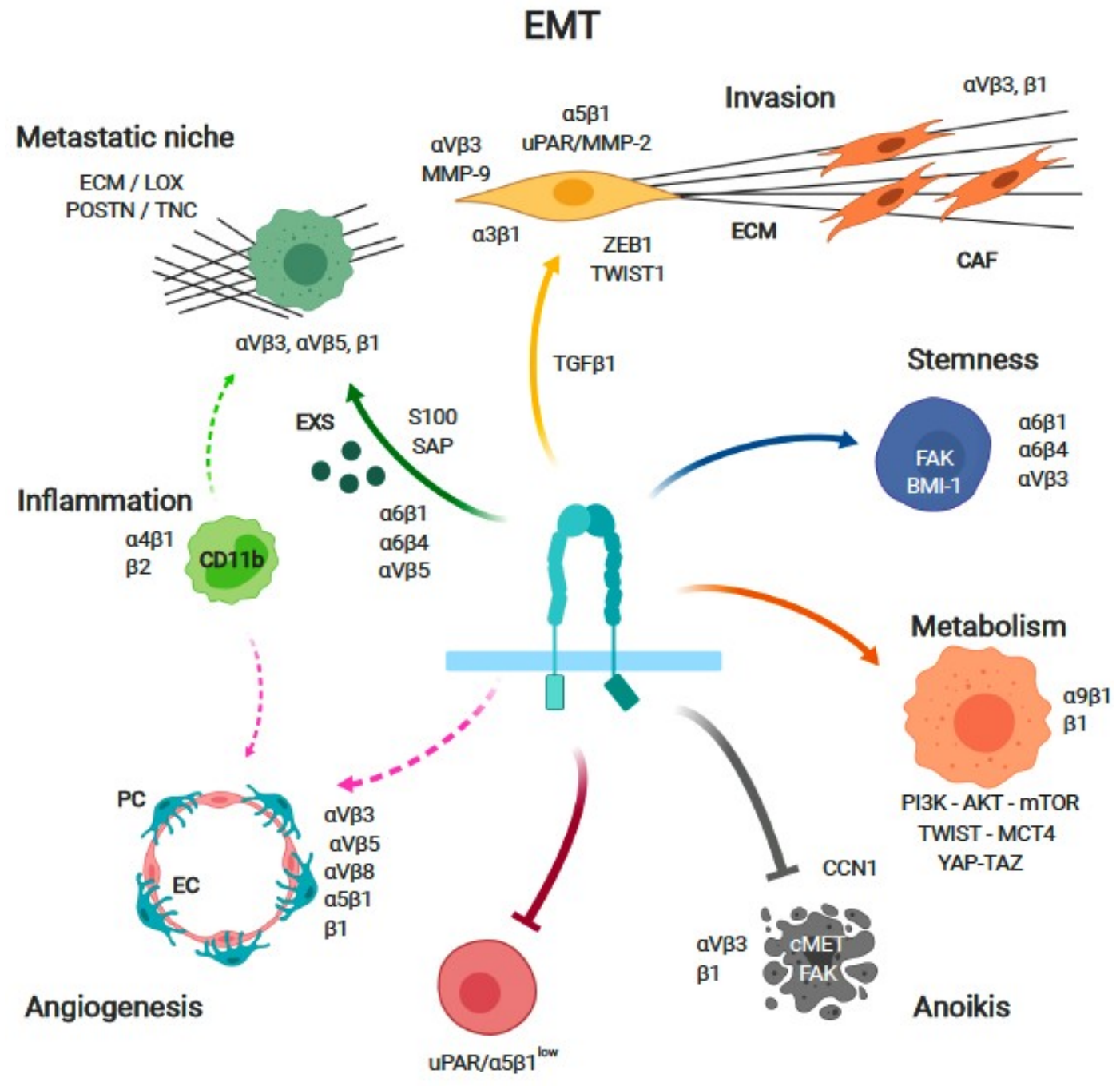

\section{Metastatic dormancy}

Figure 1. Integrin-dependent functions relevant to cancer. Integrins have been implicated in mediating several hallmarks of cancer, including cancer cell proliferation, dormancy, survival, stemness, metabolic adaptation, and metastatic niche formation. Integrins also promote epithelial-to-mesenchymal transition and invasion, which are two key steps of metastasis formation. In the tumor microenvironment, integrins promote endothelial cell survival and angiogenesis, the recruitment of immune and inflammatory cells, and stroma remodeling and fibrosis induced by cancer-associated fibroblasts. The role of integrins in these functions are described in more detail in Sections 4.1-4.6 and 5.1, and 5.2. This listing is non-exhaustive. Abbreviations: CAF, cancer-associated fibroblasts; CCN1, cysteine rich protein 61 (CYR61); CSC, cancer stem cell; endothelial cell; EC, endothelial cells, ECM, extracellular matrix; EMT, epithelial to mesenchymal transition; EXS, exosomes; LOX, lysyl oxidase; PC, pericytes; POSTN, periostin; TC, tumor cell; TNC, tenascin.

\subsection{Epithelial-to-Mesenchymal Transition (EMT) and Cancer Invasion}

Epithelial cancer cells can undergo a complex, multistep gene expression reprogramming process referred to as epithelial-mesenchymal transition (EMT), culminating with the down-regulation of epithelial-specific genes and the up-regulation of mesenchymal specific ones, which are associated with increased motility, invasion, and metastasis [46]. Integrins play an important role in the induction of EMT and in mediating some of its effects. For instance, integrin $\alpha 3 \beta 1$ expression is required for TGF 31 -stimulated Small Mothers Against Decapentaplegic (SMAD) signaling, leading to EMT [47,48]. On the other side, epithelial cells stimulation with TGF $\beta 1$ leads to a down-regulation of $\beta 4$ integrin, 
which is a typically epithelial integrin essential for epithelial integrity and stability, resulting in facilitated migration (see Figure 1) [49]. The signaling axis PEAK1/ZEB1 is mediating TGF $\beta 1$-induced EMT in breast cancer through integrin $\beta 3$ and fibronectin interaction [50]. In turn, integrins are critical mediators of EMT. For example, the transcription factors TWIST1 and AP-1 cooperate to upregulate integrin $\alpha 5$ expression to induce EMT and tissue invasion [51]. Mechanisms of invasion are quite universal and shared by most tissues and cells. They include guidance by integrins toward fibrillar collagen and/or laminins, haptotactic migration though chemokines and growth factors, and physical pushing [52]. Cancer cell invasion occurs preferentially along pre-existing ECM tracks of least resistance, followed by tissue remodeling. For example, invasive breast cancer cells preferentially invade along collagen bundles and adipocytes. Matrix remodeling/degradation, in concert with integrins function, is key to invasion. The elongation factor-2 kinase (eEF-2K) regulates the invasive phenotype of pancreatic cancer cells by activating a signaling axis consisting of tissue transglutaminase (TG2) and the $\beta 1$ integrin/uPAR/MMP-2 complex as well as a decrease in SRC activity [53]. The $\alpha \mathrm{V} \beta 3$ integrin in turn controls matrix metalloproteases 9 (MMP9) activity during invasion by binding to its Hemopexin (PEX) domain, resulting in controlled pericellular proteolysis [54]. Invasive migration and proteolytic remodeling of the ECM are interdependent processes that control tissue micropatterning events that are critical for the transition from collective to individual cancer cell invasion [55]. Importantly, cancer cells do not only invade through integrin-mediated interaction with the ECM, but can also do so by ameboid migration by a push-and-pull mechanism in the absence or integrin engagement and metalloproteases $[35,56,57]$.

\subsection{Anoikis}

Anchorage-dependent cell survival and growth are essential functions of integrin-mediated adhesion to the ECM. Upon cell detachment from the ECM, integrin clustering and the adhesome are disrupted, resulting in the dispersion of GFRs, loss of cell signaling, and cell death (anoikis) [58]. However, recent studies suggest that in non-adherent cells, integrins may still be in an active signaling state through the binding of ECM fragments or soluble ligands, and contribute to promote anchorage-independent cancer cell survival, growth, and metastasis. Active FAK, which is a critical transducer of integrin-mediated survival, is observed in $\beta 1$ integrin-positive endosomes, where it may contribute to initiate cell survival signals in cells in suspension [59]. Similarly, $\alpha \mathrm{V} \beta 3$-positive adhesomes promote SRC-CAS (Rous sarcoma oncogene cellular homolog-Crk-associated substrate)-dependent cell survival independently of FAK and cell adhesion, thereby pointing to a role for $\alpha \mathrm{V} \beta 3$ anchorage-independent tumor cell growth, survival, and aggressiveness [60]. CCN proteins associate to the ECM and bind to integrins or cell surface proteoglycans to regulate cell proliferation, motility, and differentiation [10]. We have previously shown that the matricellular CCN1 (CYR61) promotes the lung metastasis of triple negative breast cancer (TNBC) cells by binding to active $\beta 1$ integrin at the cell surface and promoting AMP-activated protein kinase $\alpha$ (AMPK $\alpha$ ) signaling, survival, and early colonization of the lung [61]. Recent observations indicate that integrin-GFRs cross-talk may persist in detached cells to provide survival signals. cMET (or Hepatocyte Growth Factor Receptor) activation stimulates the endocytosis of active $\beta 1$ integrin, which in turn sustains cMET signaling to the MAPK pathway, resulting in anchorage-independent growth and metastasis (see Figure 1) [62]. This observation, in addition to the previously reported cross-talk between the $\beta 1$ and $\beta 4$ integrins and cMET signaling, suggests that targeting integrins may enhance the anti-tumor activity of cMET inhibition in adherent and non-adherent cancer cells $[63,64]$. Thus, the role of integrins in promoting survival may not be restricted to conditions of cell adhesion to the ECM, but may further continue once cells are detached, thereby opening unanticipated therapeutic options.

\subsection{Metabolism}

Several pathways controlling metabolic functions, such as such as AMPK, mammalian target of rapamycin (mTOR), and hypoxia-inducible factor (HIF) in response to nutrients' availability and needs, 
also control integrin expression and function $[65,66]$. In turn, integrins control metabolic functions, thereby establishing a reciprocal, dynamic communication between cell adhesion and metabolism [67]. Metabolic events regulate integrin expression and function at the levels of transcription, degradation, recirculation, and glycosylation. These mechanisms and their impact on integrin biology have been recently summarized and discussed in excellent review articles, and thus will not be addressed here $[67,68]$. Instead, we will briefly highlight the modulation of metabolism by integrins. $\beta 1$ integrins activate the PI3K-AKT pathway via FAK or ILK, AKT, and mammalian Target of Rapamycin Complex 1 (mTORC1) [42]. mTORC1 is a critical regulator of the reprogramming of lipids, nucleotides, and amino acids metabolisms, and an inducer of the EMT promoter TWIST [69-71]. Integrin-mediated adhesion, PI3K-AKT signaling, and MAPK signaling promote cell survival during times of nutrient deprivation, for instance in hypoxic tumor regions, through the induction of autophagy [72]. Integrin-ILK dependent signaling also controls the Hippo signaling pathway, which is a critical nutrient-sensing system, leading to the Yes-Associated Protein/Tafazzin (YAP/TAZ)-dependent transcription of proliferation and cell survival genes. It is interesting that tenascin-C (TNC), an ECM protein promoting invasion and metastasis, modulates YAP via binding to $\alpha 9 \beta 1$ integrin [73]. Thus, integrin signaling during EMT contributes to coordinate the concomitant global changes in cell metabolism that are relevant for cell proliferation, migration, and survival [74-77]. Integrin signaling is also involved in the metabolic reprogramming of cancer cells from oxidative phosphorylation toward glycolysis and biosynthesis. TWIST induces aerobic glycolysis in breast cancer cells via $\beta 1$ integrin signaling through the FAK-PI3K-Akt-mTOR axis [78]. Consistent with this, integrins also control glucose transport, and in breast cancer cells, the loss of adhesion reduces glucose uptake, ATP production, and fatty acid oxidation [79]. In migrating cells, $\beta 1$ integrin interacts with the lactate transporter Mono Carboxylate Transporter 4 (MCT4) at the leading edge and integrin-mediated cell migration depends on MCT4 function to export excessive lactic acid and control intracellular $\mathrm{pH}$ (see Figure 1) [80,81]. Thus, there is emerging evidence indicating that integrins are involved in the regulation of metabolic functions at steps when cancer cells alter their interaction with the ECM or acquire novel integrin-dependent activities (e.g., motility, invasion, survival).

\subsection{Stemness and Resistance to Therapy}

Similar to normal tissues, cancers are hierarchically organized and contain cells with stem cell-like features, which are referred to as cancer stem cells (CSCs), which can drive tumor initiation, self-renewal (maintenance), resistance to therapy, relapses, and metastasis [82,83]. They are present in specific locations (niches) that are rich in particular ECM proteins such as periostin and TNC, and close to vascular cells $[84,85]$. By interacting with the surrounding ECM, integrins appear to control the balance between physiological stem cell renewal and differentiation [86]. It is of interest that most integrins that have been associated with physiological stem cells are also expressed in CSCs $[22,83]$. In particular, $\alpha 6$ integrins (i.e., $\alpha 6 \beta 1$ and $\alpha 6 \beta 4$ ) are widely expressed in CSCs in breast [87], prostate [88], colorectal [89], brain [90], and non-small cell lung [91] cancers. While integrin expression patterns have been initially used as markers to identify CSCs, it is increasingly clear that they play functional roles. Integrin $\alpha 6$ contributes to breast cancer initiation by inducing FAK-mediated expression of the polycomb complex protein B cell-specific Moloney murine leukemia virus Integration site 1 (BMI-1), which is necessary for CSCs self-renewal, via its cytoplasmic domain [92,93]. Integrin $\beta 3$ is essential for maintaining the CSC phenotype in breast [94], pancreas, and lung [95] cancers. $\alpha \mathrm{V} \beta 3$ expression distinguishes mammary luminal progenitors $\left(\beta 3^{\text {high }}\right)$ from mature luminal cells $\left(\beta 3^{\text {low }}\right)$ [96], and $\alpha \mathrm{V} \beta 3$ contributes to mediating CSC properties, including spheroid formation, tumor initiation [97], and metastasis [60]. Targeting CSCs integrins to modulate their interaction with the ECM of the stem cell niche may be of therapeutic potential. For instance, the inhibition of integrin $\alpha 6$ suppressed the CSC phenotype and impacted cancer progression in glioblastoma [90]. Thus, the modulation of CSCs function and fate is a novel emerging function of integrins in cancer (see Figure 1). 
The role of integrins in CSC biology is likely to contribute to chemoresistance and tumor relapse, which is an integrin effect that was reported earlier [98]. In breast cancer, paclitaxel (Taxol) treatment enriches high CSC for integrin $\alpha 6$ [93], and in a spontaneous lung cancer model, CSCs expressing integrin $\beta 4$ are enriched after cisplatin treatment [91]. Integrin $\beta 3$ is highly expressed in cancer cells with acquired resistance to the EGFR inhibitors to erlotinib and lapatinib through the activation of NF- $\mathrm{KB}$ signaling [95]. Integrin $\beta 1$ has been reported to promote resistance to radiotherapy in head and neck cancer [99], lapatinib and trastuzumab resistance in breast cancer [100], and erlotinib resistance in lung cancer [101] by enhancing SRC and AKT activities. Consistently, silencing integrin $\beta 1$ restored erlotinib sensitivity [101]. DNA damage can enhance $\alpha \mathrm{V} \beta 3$ expression on resistant cells, facilitating clearance by phagocytosis, and thereby dumping the immune response [102]. Consistently, the inhibition of $\alpha \mathrm{V} \beta 3$-mediated phagocytosis enhanced antibody-dependent cytotoxic responses [103]. Thus, unexpectedly, tumor cell $\alpha \mathrm{V} \beta 3$ may turn out to be a regulator of the anti-tumor immune response, thereby opening new therapeutic opportunities.

\subsection{Metastatic Niche}

Tumor cells leaving the primary tumor on the way to form metastases face their main challenge when they enter the distant organ, and need to adapt to survive in the new tissue [104]. For this, disseminated tumor cells (DTC) rely on a specialized microenvironment called the metastatic niche, promoting their survival and outgrowth $[105,106]$. The recruitment of inflammatory/bone marrow-derived cells and endothelial cells, through the production of growth factors, cytokines, and chemokines, the modification of the ECM, and, paradoxically, hypoxia, are essential elements of the niche [107-110]. Metastatic niches can be induced by primary tumors even before DTC reach the peripheral tissues, and are therefore also referred to as pre-metastatic niches. This implies a cross-talk between the primary tumor and peripheral tissues [111,112]. Inflammation is a key element of this cross-talk and the (pre)metastatic niche formation. Pro-inflammatory factors, such as S100 or Serum Amyloid A acute phase Proteins (SAP) family members induced by the primary tumor, play a critical role in the formation of (pre)metastatic niches, including the recruitment of CD11b+ myeloid cells [113]. Exosomes released by cancer cells promote metastasis by contributing to the formation of organ-specific (pre)-metastatic niches through their ability to transfer metabolites, proteins, and RNA to distant tissues [114-116]. Strikingly, integrins enriched on the surface of cancer-derived exosomes contribute to organ-specific targeting. For instance, exosomes shed by cancer cells metastasizing to the lung are enriched for $\alpha 6 \beta 1$ and $\alpha 6 \beta 4$ integrins, which home themselves to the lung, while $\alpha \mathrm{V} \beta 5$ integrin-rich exosomes shed by liver-tropic cancer cells are that preferentially home to the liver (see Figure 1) [116]. Once in the target organ, exosomes actively contribute to the formation of the (pre)metastatic niche by inducing the expression of specific ECM proteins and pro-inflammatory factors, including S100 proteins favoring the recruitment of inflammatory cells [116]. Further research is necessary in order to evaluate the clinical significance of these observations, and in particular whether impinging on the integrins-mediated homing of tumor-derived exosomes may have an adjuvant therapeutic effect on metastatic tumor progression. On the other side, circulating exosomes may be exploited to identify patients progressing to metastasis.

\subsection{Metastatic Dormancy}

DTC can remain quiescent for prolonged periods of time as single cells, small clusters, or micrometastases before resuming growth to form macrometastases in a state called metastatic dormancy $[117,118]$. This is particularly relevant for breast cancer, where clinical relapses can occur years or decades after primary cancer therapy $[119,120]$. Interaction with the ECM is implicated in controlling dormancy, paralleling the role of cell-ECM interaction in physiological CSC niches [121]. For example, high Urokinase-type Plasminogen Activator Receptor (uPAR) expression and $\alpha 5 \beta 1$ integrin binding to fibronectin suppresses p38 activity, increases ERK activity, and promotes cell proliferation. Accordingly, low uPAR-expressing cells have a high p38/Extracellular Regulated Kinase 
(ERK) activity ratio, fail to assemble fibronectin fibrils and ligate $\alpha 5 \beta 1$ integrin, and are dormant in vivo [122]. Similarly, the loss of $\alpha 5 \beta 1$ integrin expression results in the inactivation of the RAS-Rat Fibrosarcoma (RAF)-ERK signaling pathway, the activation of p38/Janus N-Terminal Kinase (JNK) stress signaling pathway, the induction of the TP53/RB-dependent cell-cycle arrest, and dormancy (see Figure 1) [123]. This suggests a role for the cross-talk between mitogenic and stress signals regulated by the uPAR- $\alpha 5 \beta 1-E C M$ axis in controlling cellular dormancy [124]. Interestingly, collagen-rich (fibrotic) ECM promotes the transition of dormant DTC to growing DTCs [121,125-127]. Accordingly, $\beta 1$ integrin ligation mediates the awakening of dormant DTC in a murine breast cancer model [121]. The ECM protein periostin, which is a $\alpha \mathrm{V} \beta 3$ and $\alpha \mathrm{V} \beta 5$ ligand present in the primary and metastatic tumor stroma, drives DTC escape from dormancy by activating Wingless Int-1 (WNT) signaling [128,129]. Inhibition of the PI3K-AKT signaling cascade, which is a pathway also controlled by integrins, can activate autophagy and induce quiescence [130], while low or absent AKT signaling in DTC correlates with dormancy in breast cancer patients $[130,131]$. Consistently, dormant tumor cells express high levels of Aplysia Ras Homology Member I (ARHI), which is an inhibitor of the PI3K-AKT cascade, and ARHI silencing breaks dormancy in several experimental models [132,133]. Thus, controlling cancer dormancy is emerging as an unanticipated activity of integrins, and interfering with ECM integrins interaction may be a therapeutic approach to consider in order to promote cancer dormancy $[134,135]$. Further studies are warranted to unravel their potential operability in patients at risk for progression or recurrence after initial therapy, particularly radiotherapy.

\section{Tumor Stroma}

The tumor microenvironment (TME) contains a multitude of cells that positively or negatively impact tumorigenesis, tumor growth, invasion, and metastasis, two of which are fibroblasts and endothelial cells [136]. Integrins expressed on these cells participate in the cross-talk relevant to tumor progression.

\subsection{Fibroblasts and the Extracellular Matrix}

Altered composition of the tumor ECM, such as increased fibrillar collagen deposition, cross-linking, and rigidity provide guidance cues and oncogenic signals for cancer cell growth and invasion in multiple cancers, including breast, colorectal, head and neck, and pancreas [137]. Matrix cross-linking through lysil oxydases (LOXs) increases matrix stiffness, integrin-dependent signaling, and SRC-dependent cell proliferation, resulting in facilitated tumor progression and metastasis [30,138-140]. Altered collagen deposition, ECM modification, and increased cancer-associated fibroblasts (CAF) contractility may be a general hallmark of tumor progression and poor prognosis, and therefore a potential therapeutic target [137]. We recently reported a novel mechanism by which CAF induces contact-dependent Colorectal Cancer CRC cell motility and invasion. Activated fibroblasts express FGF-2 on their surface and present it to FGF receptors (FGFR) on CRC cells, resulting in integrin $\alpha \mathrm{V} \beta 5$-dependent CRC cell migration along fibroblasts. The inhibition of FGF- 2 on fibroblasts or FGFR, SRC, and $\alpha \mathrm{V} \beta 5$ on cancer cells prevented these effects (see Figure 1) [141]. By using an orthotopic model of CRC, we validated in vivo these in vitro results. The co-injection of CRC cells with fibroblasts in the cecum of mice promoted lung metastasis, which was prevented by treatment with the SRC and FGFR kinase inhibitors dasatinib and erdafitinib, respectively [142]. These experiments suggest that the FGF2-FGFR-SRC $-\alpha V \beta 5$ integrin axis might be a potential therapeutic target to prevent metastasis in stage II and III CRC. In a previous study, we identified the matricellular protein CCN1 and $\alpha \mathrm{V} \beta 5$ integrin as proteins cooperating to mediate the invasion and metastasis of tumors growing in hypoxic pre-irradiated tissues. $\alpha \mathrm{V} \beta 5$ inhibition by a pan-anti-anti- $\alpha \mathrm{V}$ monoclonal antibody $(\mathrm{mAb}) 17 \mathrm{E} 6$ or the $\alpha \mathrm{V} \beta 3 / \alpha \mathrm{V} \beta 5$-specific cyclic Arg-Gly-Asp peptide cilengitide [143] attenuated CYR61/CTGF/NOV1 (CCN) 1-dependent metastasis [144]. Thus, integrins are important mediators of the interaction of tumor cells, CAF, and matricellular proteins relevant to tumor progression, and are therefore of potential therapeutic relevance. 


\subsection{Endothelial Cell}

$\alpha \mathrm{V} \beta 3$ was the first integrin reported to be preferentially expressed in angiogenic endothelial cells [145]. The inhibition of $\alpha \mathrm{V} \beta 3$ through antibodies, Arg-Gly-Asp-based cyclic peptides, or non-peptidic mimetics suppressed tumor angiogenesis without affecting quiescent endothelial cells. In preclinical studies, the inhibition of angiogenesis with $\alpha \mathrm{V} \beta 3$ antagonists suppressed tumor progression, raising a high expectation that $\alpha \mathrm{V} \beta 3$ inhibition may be a valuable anti-cancer strategy (see Figure 1) $[9,146]$. However, genetic ablation of the $\alpha \mathrm{V}$ or $\beta 3$ subunit had minimal impact on developmental angiogenesis [147,148], while it increased VEGFR-2 signaling and tumor angiogenesis [149,150]. Interestingly, the acute genetic deletion of endothelial cell $\alpha \mathrm{V} \beta 3$ transiently suppressed tumor angiogenesis if performed before tumor implantation, but not once tumors were already growing [151]. Low concentrations of high affinity Arg-Gly-Asp-based peptidic inhibitors such as cilengitide induce $\alpha \mathrm{V} \beta 3$ affinity maturation and signaling, resulting in stimulated angiogenesis [152]. These observations question the relevance of $\alpha \mathrm{V} \beta 3$ as a target in anti-angiogenesis therapies. High-affinity inhibitors disrupt the Vascular Endothelial (VE)-cadherin junction, and increase permeability through $\alpha \mathrm{V} \beta 3$ activation and FAK-SRC signaling in vitro [153]. These effects translated into increased vascular permeability of $\alpha \mathrm{V} \beta 3$-positive tumor vessels in tumor-bearing mice treated with cilengitide, resulting in increased chemotherapy delivery to the tumor relative to healthy tissue [154]. Interesting, the $\alpha \mathrm{V} \beta 3$ function appears to be modulated by inflammatory factors. A combined administration of high doses of Tumor Necrosis Factor/Interferon gamma (TNF/IFN $\gamma$ ) through an isolation limb perfusion setting to cancer patients with sarcomas or melanoma metastases of the limbs inactivates endothelial cell $\alpha \mathrm{V} \beta 3$, causing endothelial cell death and selective disruption of the tumor vasculature [155]. Inactive $\alpha \mathrm{V} \beta 3$ integrin acts permissive for TNF to kill endothelial cells through a lack of AKT activation and anti-apoptotic signals [156]. Prostaglandin E2 $\left(\mathrm{PGE}_{2}\right)$ promotes tumor angiogenesis by activating $\alpha \mathrm{V} \beta 3$ function and signaling through the prostane receptors cyclic Adenosine Monophosphate (cAMP), Protein Kinase A (PKA) and RAC, and these effects are blocked by Cyclooxygenase-2 COX-2 inhibition [157]. However, endothelial cells express many additional integrins beyond $\alpha \mathrm{V} \beta 3 / \alpha \mathrm{V} \beta 5$, including $\alpha 4 \beta 1, \alpha 5 \beta 1$ (fibronectin receptors), $\alpha 9 \beta 1$ (tenascin receptor), $\alpha 3 \beta 1, \alpha 6 \beta 1$ and $\alpha 6 \beta 4$ (laminin receptors), and $\alpha 1 \beta 1$ and $\alpha 2 \beta 1$ (collagen receptors) [158]. Due to the overlap of integrin expression across different cell types and tissues, the selective targeting of integrins to inhibit tumor angiogenesis remains challenging. Nevertheless, the inhibition of $\alpha 1 \beta 1, \alpha 2 \beta 1$, $\alpha 5 \beta 1$ suppressed tumor angiogenesis and reduced tumor growth in many experimental models [9,159].

However, clinical trials with the $\alpha \mathrm{V} \beta 3$ integrin inhibitors cilengitide [143] failed to demonstrate significant therapeutic benefits, including in highly angiogenic glioblastoma [160]. Considering the failures of other anti-angiogenic therapies (e.g., the anti-VEGF antibody bevacizumab) in halting glioblastoma progression, the failure of cilengitide as anti-angiogenic drug [143] may not be due to cilengitide itself, but rather to limitations intrinsic to all anti-angiogenic approaches, in particular evasive resistance [161-163].

In summary, integrin inhibition as an anti-cancer therapy was initially conceived based on the role of integrins in promoting cancer cell invasion, metastasis, and tumor angiogenesis. Recent developments indicate that additional functions relevant to cancer cells are also mediated or regulated by integrins, including dormancy, metabolism, survival, therapy resistance, EMT, fibrosis, cancer cell stemness, exosome homing, and pre-metastatic niche formation. Thus, in the future, it will be important to understand the contribution of integrins to these emerging functions, and evaluate the potential therapeutic impact of impinging on these functions by inhibiting integrins.

\section{Targeting Integrins in Cancer}

Antibodies, endogenous proteins, peptidic antagonists, synthetic peptides, and peptidomimetics have been used to target integrins in cancer. Some of these molecules were or are still in clinical development, but none of them have been successfully established as an anti-cancer agent to date [30,164]. 


\subsection{Inhibiting Integrin Function}

Anti- $\alpha \mathrm{V} \beta 3$ antibody etaracizumab (MEDI-522) entered phase I and II clinical studies and showed good tolerability, also in combination with chemotherapy, but no anti-angiogenic or immunomodulatory effects were noted $[165,166]$. Anti- $\alpha \mathrm{V}$ antibodies, such as intetumumab (CNTO95) or abituzumab (EMD 525797/DI17E6) entered phase I and II clinical testing as single agents or in combination with cytotoxic agents and/or other targeted molecules. Clinical trials were initiated in a variety of solid tumors, including melanoma, sarcoma, colorectal, and prostate cancers [167,168]. Abituzumab showed specific activity in prostate cancer bone metastases [169]. A randomized, double-blinded phase 2 study of abituzumab in combination with the EGFR inhibitor cetuximab and Laucovorin, Fluorouracil, Irinotecan (FOLFIRI) chemotherapy in first-line RASWT metastatic $\mathrm{CRC}$ with high $\alpha \mathrm{V} \beta 6$ integrin expression is planned and expected to be completed in August 2021 (www.clinicaltrials.gov/NCT03688230). The anti- $\alpha 5 \beta 1$ integrin antibody M200/volociximab was shown to inhibit angiogenesis and suppress tumor growth and metastasis in mice [170]. It entered clinical testing as a single agent in advanced epithelial ovarian or primary peritoneal cancer [171] and in combination with chemotherapy in advanced non-small-cell lung cancer (NSCLC) [172]. Volociximab was generally well tolerated, and showed preliminary evidence of efficacy in advanced NSCLC. Endogenous antagonists such as the peptides endostatin, tumstatin, or angiostatin showed anti-cancer activity profiles [9]. Recombinant endostatin, a supposed $\alpha 5 \beta 1$ inhibitor, was tested in clinical studies in combination with chemotherapies and radiotherapies [173,174], but the results have been inconsistent, which also relates to problems in the production of the active protein [175].

The Arg-Gly-Asp-based cyclic peptide cilengitide (EMD121974) targeting $\alpha \mathrm{V} \beta 3 / \alpha \mathrm{V} \beta 5$ has been the most advanced and investigated integrin inhibitor so far [143]. In spite of preclinical evidence of anti-cancer activity and great expectations from phase II clinical studies [176], phase III studies, in combination with chemotherapy, targeted agents, or radiotherapy in a multitude of cancers-most notably glioblastoma-failed to provided clinical benefits $[6,7,160,177,178]$. The $\alpha 5 \beta 1$-blocking non Arg-Gly-Asp-based peptide ATN-161 entered clinical testing [179] based on preclinical anti-cancer activities [180,181], but also failed to provide therapeutic benefits. It is currently being investigated in combination with VEGF inhibition for the treatment of wet age-related macular degeneration [182].

Peptidomimetics are synthetic compounds mimicking the structure and action of natural peptides that have the advantages of being insensitive to protease degradation, able to be administered orally, and having longer stability. Many peptidomimetics targeting $\alpha \mathrm{V} \beta 3, \alpha \mathrm{V} \beta 5$, and $\alpha 5 \beta 1$, including SCH221153, BCH-15046, SJ749, and JSM6427 have been developed and showed anti-cancer activities in preclinical models $[9,164]$.

\subsection{Targeting Drug to the Tumor}

A conjugation of integrin-targeting antibodies, Arg-Gly-Asp-based cyclic peptides, or peptidomimetic, has been explored to improve the delivery and tumor uptake of drugs, biologicals, nanoparticles, and liposomes compared to unconjugated drugs [183,184]. For example, $\alpha$ V $\beta 3$-specific Arg-GlyAsp-based cyclic peptides targeting the tumor vasculature or tumor cells have been successfully used to deliver therapeutic compounds, as well as image tumor lesions (theranostics) $[185,186]$. In general, these approaches have demonstrated superior ability in increasing drug uptake and activities in the tumors (reviewed in [185,187-190]). Dual targeting has further significantly improved drug delivery and activity. Utilizing peptides against $\mathrm{P}$-selectin and $\alpha \mathrm{V} \beta 3$, which are two molecules that are functionally implicated in different stages of the metastatic disease, significantly increased drug delivery at metastatic sites, compared to a single molecule targeting [191]. Similarly, dual $\alpha V \beta 3$ (vascular)/CD44 (cancer cell) targeting resulted in enhanced targeting efficiency and anti-tumor activities through the enhanced permeation and retention effect [192,193]. Cell-penetrating peptides can be combined with targeting peptides to improve drug delivery. For instance, tumor targeting through a tumor-specific peptide, followed by proteolytic cleavage and binding to a second receptor, improved delivery by facilitated extravasation and transport through extravascular tumor 
tissue [194]. Magnetic nanoparticles (magnetosomes) coupled to Arg-Gly-Asp peptides were targeted to tumors after systemic administration and used to generate therapeutic heat upon laser excitation, which successfully inhibited tumor progression [195].

\subsection{Tumor Imaging}

Integrin $\alpha \mathrm{V} \beta 3, \alpha 5 \beta 1$, and $\alpha \mathrm{V} \beta 6$ have been explored for non-invasive tumor imaging purposes, using magnetic resonance imaging (MRI), positron emission tomography (PET), computer tomography (CT), and optical and ultrasound-based imaging techniques $[9,196,197]$. Their targeting is of great potential relevance for the early diagnosis, staging of disease, patient's stratification, and therapeutic monitoring [198]. The imaging of experimental tumors using modified $\alpha \mathrm{V} \beta 3$-binding Arg-Gly-Asp (RGD)-based peptides is a standard benchmark for the validation of tumor-targeting approaches [28]. PET technology has been preferred for use in animal models and in humans because of its high intrinsic sensitivity. The level of expression of $\alpha \mathrm{V} \beta 3$ detected by PET correlated with the level of $\alpha \mathrm{V} \beta 3$ determined by immunohistochemistry, suggesting that this approach is a good surrogate of integrin expression in vivo $[197,199,200]$. Tracers targeted by anti- $\alpha \mathrm{V}$ integrin antibodies or peptides showed high levels of specific tumor accumulation by PET, Single Photon Emission Computed Tomography (SPECT), or optical imaging in different cancer models [201-205]. In spite of these interesting results, the clinical value of the in vivo mapping of $\alpha \mathrm{V} \beta 3$ to quantify tumor angiogenesis has not been clinically validated yet, as $\alpha \mathrm{V} \beta 3$ expression itself does not necessarily correspond to angiogenic activity in tumor tissues [200,206]. Integrin $\alpha 5 \beta 1$ has also been explored for PET and SPECT-based imaging of experimental tumors using peptidomimetic, linear, or cyclic peptides [207-209], while $\alpha 5 \beta 1$-based imaging in human has not been reported yet [28]. $\alpha \mathrm{V} \beta 6$-based imaging may be attractive, as it is associated with the invasion and activation of the TGF $\beta$ pathway in tumor cells. Using a $\alpha \mathrm{V} \beta 6$ peptide ligand identified by phage display library screening PET/CT-based scans successfully imaged head and neck cancers and NSCLC [210]. Interestingly, Nieberler et al. used a highly potent $\alpha \mathrm{V} \beta 6$-selective integrin ligand [211] for fluorescence-assisted intraoperative assessment of resection margins in patients with bone-infiltrating squamous cell carcinoma of the head and neck [212]. This approach could become an invaluable intraoperative guidance tool for the surgeons to assure tumor-free resection margins.

\section{Open Questions and Challenges Ahead}

Over 30 years of experimental research has provided compelling evidence that integrins are important mediators of cancer progression, and preclinical results indicate that they are potentially valuable therapeutic targets, in particular $\alpha \mathrm{V} \beta 3$ and $\alpha 5 \beta 1$, for anti-cancer therapies. Yet, to date, numerous clinical studies have failed to translate preclinical expectations into therapeutic benefits for patients (Table 2). The failure of cilengitide, the integrin antagonist that has been most widely tested in randomized clinical studies [143], was a major deception. After a large phase III trial evaluating cilengitide in combination with radiation and temozolomide chemotherapy in newly diagnosed glioblastoma failed to show any sign of activity, the further development of this anticancer drug was halted, and the interest in $\alpha \mathrm{V} \beta 3$ integrin inhibition as a therapeutic target has dwindled [6,7]. Likewise, the anti- $\alpha \mathrm{V} \beta 3$ antibody etaracizumab also failed to demonstrate significant therapeutic activity in patients with melanoma. In contrast, the anti- $\alpha \mathrm{V}$ antibody abituzumab has shown modest activity in recurrent KRAS WT colorectal cancer, and is currently being tested in a larger randomized phase II clinical trial. Likewise, the $\beta 1$ inhibitor volociximab, in spite of encouraging preliminary results, has also failed to demonstrate therapeutic benefits. 
Table 2. Selected clinical trials of agents targeting integrins. Non-exhaustive listing of the recent most important clinical studies with integrin inhibitors and their salient features and results).

\begin{tabular}{|c|c|c|c|c|c|c|}
\hline Study Name and Description & Indication & Phase/N pts & Design & Endpoints & Outcome and Remarks & References \\
\hline \multicolumn{7}{|c|}{ Abituzumab (EMD 525797, anti- $\alpha \mathrm{V}$ integrin antibody) (Merck-Serono): total no. of trials 3} \\
\hline POSSEIDON: SofC \pm abituzumab (two doses) & Colon Ca (KRAS WT) & $\begin{array}{c}\text { II } \\
216\end{array}$ & dose finding/randomized & $\begin{array}{l}1^{\mathrm{o}}: \text { PFS } \\
2^{\mathrm{o}}: \text { OS }\end{array}$ & $\begin{array}{l}\text { No diff in PFS, superior surv. of both } \\
\text { abituzumab arms vs. SoC. }\end{array}$ & [213] \\
\hline AMELION: Cetuximab/FOLFIRI \pm Abituzumab, high $\alpha \mathrm{V} \beta 6$ expr. & Colon Ca & $\begin{array}{c}\text { II } \\
230\end{array}$ & Randomized & $\begin{array}{c}1^{\mathrm{o}}: \text { PFS } \\
2^{\mathrm{o}}: \text { OS, RR }\end{array}$ & Start planned for 2nd quarter 2019 & NA \\
\hline \multicolumn{7}{|c|}{ Intetumumab (CNTO95, anti- $\alpha \mathrm{V}$ integrin antibody) (Centocor, Johnson \&Johnson): total no. of trials: 3} \\
\hline Intetuzumab \pm DTIC vs. DTIC & Melanoma & $\begin{array}{c}\text { II } \\
129\end{array}$ & $\begin{array}{l}\text { randomized } \\
(4 \text {-arms })\end{array}$ & $\begin{array}{l}1^{\circ}: \text { PFS: } \\
2^{\circ}: \text { OS, RR }\end{array}$ & $\begin{array}{l}\text { Trend for improved OS with } \\
\text { high-dose intetumumab }\end{array}$ & [214] \\
\hline Docetaxel \pm intetumumab & Prostate Ca & $\begin{array}{c}\text { II } \\
131\end{array}$ & Randomized & $\begin{array}{l}1^{\mathrm{o}}: \mathrm{PFS} \\
2^{\mathrm{o}}: \mathrm{RR}\end{array}$ & Outcome favors placebo $(!)$ & [215] \\
\hline \multicolumn{7}{|c|}{ Cilengitide (EMD 121974, anti- $\alpha \mathrm{V} \beta 3 / \alpha \mathrm{V} \beta 5$ integrin cyclic peptide) (Merck-Serono): total no. of trials: 21 (+ 8 terminated) } \\
\hline $\begin{array}{l}\text { ADVANTAGE: CDDP/5-FU/Cetuximab } \pm \text { cil weekly vs. } 2 \times / \text { wk vs. } \\
\text { control }\end{array}$ & Rec/metast. H\&NCa & $\begin{array}{c}\text { II } \\
184\end{array}$ & 3-arms & $\begin{array}{l}1^{\circ}: \text { PFS: } \\
2^{\circ}: \text { OS, RR }\end{array}$ & No difference in $1^{\circ}$ or $2^{\circ}$ endpoints & [216] \\
\hline CERTO: CDDP-based regimen \pm cilengitide weekly or $2 \times /$ week & NSCLC & $\begin{array}{c}\text { II } \\
169 \\
\end{array}$ & Randomized/dose-finding & $\begin{array}{l}1^{\circ}: \text { PFS } \\
2^{\mathrm{o}}: \text { OS }\end{array}$ & Inconsistent results & [217] \\
\hline NABTT:0306: Cil 500 vs. $2000 \mathrm{mg}+\mathrm{TMZ} / \mathrm{RT} \rightarrow \mathrm{TMZ}$ & nd GBM & $\begin{array}{c}\text { II } \\
112\end{array}$ & Randomized & OS & $\begin{array}{l}\text { Both arms improved over historical } \\
\text { controls }\end{array}$ & [218] \\
\hline Cil 500 vs. $2000 \mathrm{mg}$ & Rec GBM & $\begin{array}{l}\text { II } \\
81\end{array}$ & Randomized & $\mathrm{PFS}_{6 \mathrm{mo}}$ & Responses at all doses & [219] \\
\hline Cil $2000 \mathrm{mg}$ & Prostate & $\begin{array}{l}\text { II } \\
16\end{array}$ & $\begin{array}{l}\text { Uncontrolled, 2-stage } \\
\text { design }\end{array}$ & PSA response & No activity & [220] \\
\hline 010: Cil (500 mg) + TMZ/RT $\rightarrow$ TMZ & nd GBM & $\begin{array}{l}\text { II } \\
52\end{array}$ & Pilot study, uncontrolled & $\begin{array}{l}1^{\circ}: \mathrm{PFS}_{6 \mathrm{mo}} \\
2^{\circ}: \text { OS }\end{array}$ & Comparison to historical control & [221] \\
\hline CENTRIC: TMZ/RT $\rightarrow \mathrm{TMZ} \pm \mathrm{Cil}$ & $\begin{array}{l}\text { Methyl. MGMT } \\
\text { GBM }\end{array}$ & $\begin{array}{l}\text { III } \\
545\end{array}$ & $\begin{array}{l}\text { Pivotal international } \\
\text { EORTC trial. }\end{array}$ & OS & No activity & [6] \\
\hline CORE: Cil 5d/week vs. 2d/wk vs. control + TMZ/RT & $\begin{array}{l}\text { Unmethyl. MGMT } \\
\text { GBM }\end{array}$ & $\begin{array}{c}\text { II } \\
265\end{array}$ & 3-arms & $\begin{array}{c}\text { OS } \\
\text { 2: PFS }\end{array}$ & No differences & [222] \\
\hline \multicolumn{7}{|c|}{ Etaracizumab (MEDI-522, anti- $\alpha \mathrm{V} \beta 3$ integrin antibody) (MedImmune, Astra Zeneca): total trial 9 (+1 discontinued early) } \\
\hline Etatacizumab \pm DTIC & Melanoma & $\begin{array}{c}\text { II } \\
112\end{array}$ & Randomized & $\mathrm{RR}, \mathrm{OS}$ & $\begin{array}{l}\text { No responses with etatcizumab } \\
\text { alone. No further evaluation } \\
\text { recommended. }\end{array}$ & [165] \\
\hline \multicolumn{7}{|c|}{ Volociximab (MEDI-522, anti $\alpha 5 \beta 1$ integrin antibody) (AbbVie): total trials 7 (+ 3 discontinued early) } \\
\hline \multicolumn{7}{|c|}{ Numerous uncontrolled phase II studies against lung, pancreatic and ovarian cancer } \\
\hline $\begin{array}{l}\text { SoC; standard of care. FOLFIRI; 5FU, le } \\
\text { PFS; progression-free survival. OS; over }\end{array}$ & $\begin{array}{l}\text { Icovorin, irinotecan. DT } \\
\text { ll survival. RR; respons }\end{array}$ & $\begin{array}{l}\text { I; dacarbazine } \\
\text { ate. } 1^{\circ} ; \text { prima }\end{array}$ & $\begin{array}{l}\text { DDP; cisplatin. TMZ; temoz } \\
\text { endpoint. } 2^{\circ} \text {, secondary end }\end{array}$ & $\begin{array}{l}\text { omide. RT; radic } \\
\text { int. Rec, recurr }\end{array}$ & $\begin{array}{l}\text { herapy. Cil; cilengitide. } \\
\text { tt; nd, newly diagnosed }\end{array}$ & \\
\hline
\end{tabular}


So, what went wrong in the development of integrins inhibitors as anti-cancer drugs? Is the choice of the target (i.e., the integrin) a problem? It is hard to imagine that the contribution of integrins to tumor development and progression observed in experimental and preclinical animal models does not apply to human cancer. Alternative, is it our still incomplete understanding of the complexity of integrin function and biology that that has mislead us toward overoptimistic approaches? Or, are the inhibitors used inappropriate? Could this be a "simple" pharmacokinetic issue, or a more "complex" problem associated with intrinsic properties of integrin that we failed to recognize? Maybe in the studied cancer types, integrins did not play a predominant role, or the lack of a biomarker for patient selection led to the failure. These are complex questions, for which today we do not have definitive answers. Nevertheless, they should stimulate us to think about developing new concepts, tools, and approaches to successfully exploit this fascinating class of molecules for the benefit of cancer patients (Figure 2).

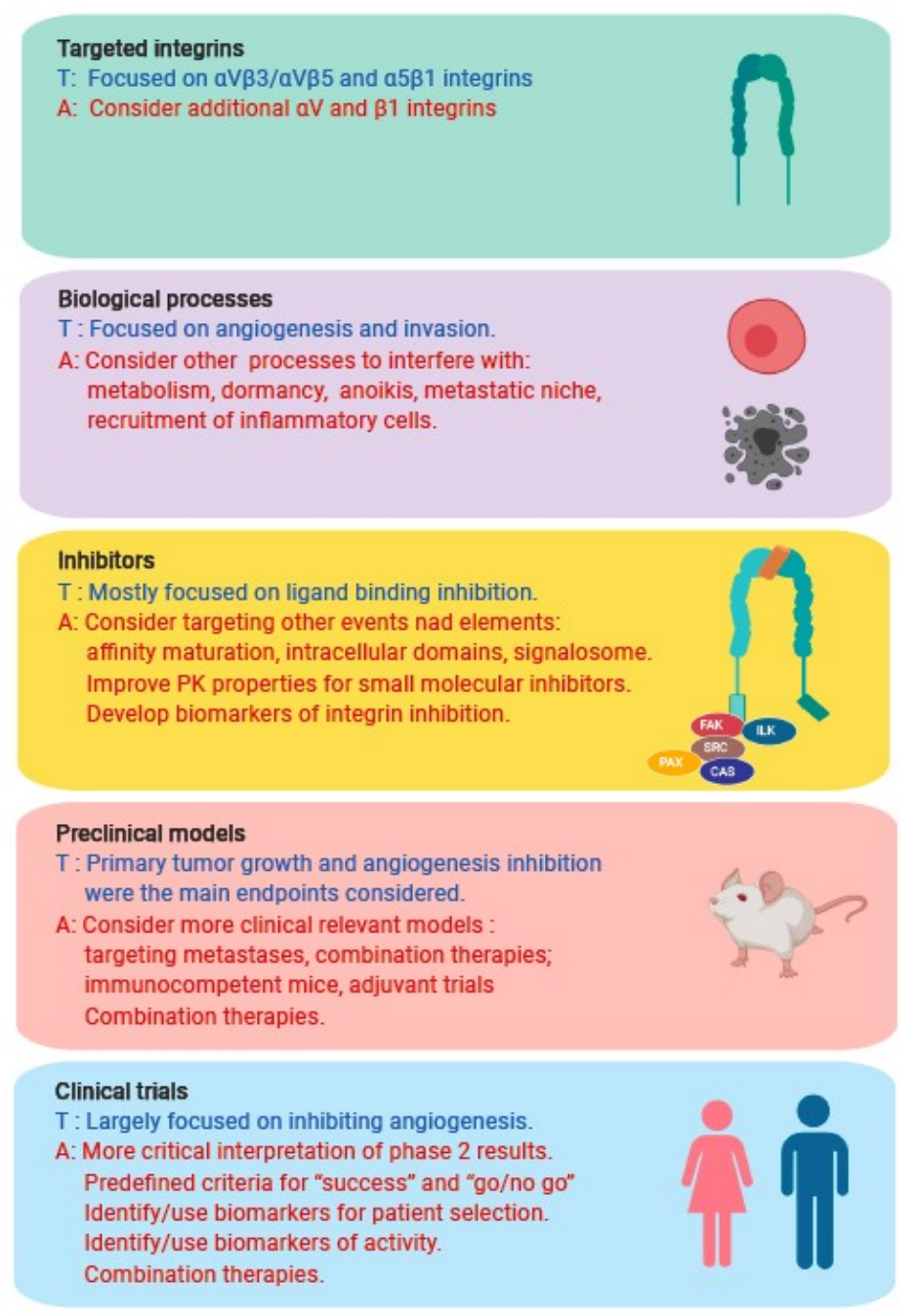

Figure 2. What went wrong with the development of integrin inhibitors in cancer, and what can we do different? The field focused largely on a few integrins, most notably $\alpha \mathrm{V} \beta 3 / \alpha \mathrm{V} \beta 5$ and $\alpha 5 \beta 1$ based on early preclinical work with the purpose to target tumor angiogenesis, using a limited set of inhibitors (mostly interfering with ligand binding). A better understanding of integrin function and biology, and the accumulated experience with clinical studies, should stimulate us to think about developing new concepts, tools, and approaches to successfully exploit integrins as therapeutic targets in cancer. Here is a non-exhaustive summary of the concepts discussed in the text. T, tested in the past to present; A, alternative strategies to consider. 


\subsection{Did We Target the Wrong Integrin(s)?}

Based on experimental results, the large majority of the 24 known integrins is implicated in cancer progression $[223,224]$. However, so far, only a few integrins have been explored clinically as therapeutic targets in anti-angiogenic therapies: $\alpha \mathrm{V} \beta 3$ and $\alpha \mathrm{V} \beta 5$, with the small cyclic peptide cilengitide; the $\alpha \mathrm{V}$ subfamily (i.e., $\alpha \mathrm{V} \beta 1 / \alpha \mathrm{V} \beta 3 / \alpha \mathrm{V} \beta 5 / \alpha \mathrm{V} \beta 6 / \alpha \mathrm{V} \beta 8$ ) with the pan anti- $\alpha \mathrm{V}$ antibody abituzumab and intetumumab; and $\alpha 5 \beta 1$ with the anti- $\alpha 5$ antibody volociximab. The role of $\alpha \mathrm{V} \beta 3$ in tumor angiogenesis have been questioned by genetic evidence, demonstrating that the constitutive ablation of the $\beta 3$ subunit increased tumor angiogenesis $[149,150]$, while conditional deletion in growing tumors had no anti-tumor effect [151]. Besides, $\alpha \mathrm{V} \beta 3$ and $\alpha \mathrm{V} \beta 5$, which are endothelial cells, express additional integrins (i.e., $\alpha 3 \beta 1, \alpha 4 \beta 1, \alpha 5 \beta 1, \alpha 6 \beta 1, \alpha 9 \beta 1, \alpha 6 \beta 4, \alpha 2 \beta 1$ ) that were not systematically considered and tested as potential therapeutic targets. The functional redundancy, promiscuity, and compensation typical of integrins may be the reasons why these integrin inhibitors were well tolerated, but at the same time had limited therapeutic effects. Redundancy and functional compensation call for testing the concomitant inhibition of multiple integrins in preclinical models. However, multiple targeting, if effective in animal models may be difficult to achieve in patients.

\subsection{Did We Use the Wrong Inhibitor(s)?}

Traditionally, integrin inhibitors have been conceived and screened for their ability to interfere with cell adhesion and migration. These inhibitors generally target the extracellular domain to prevent ligand binding, either by competitive, high-affinity occupation of the ligand-binding pocket (e.g., cilengitide), or by preventing affinity maturation or sterically hindering ligand binding (e.g., antibodies) (Figure 3) [164,225]. However, integrins have complex features (i.e., allosteric regulation, including cis interaction with other cell surface receptors and clustering at focal complexes and interaction with cytoplasmic proteins), making them unique relative to other receptors that may complicate the generation of effective inhibitors [226]. For instance, high-affinity "inhibitors" can prevent ligand binding, but at the same time, can induce a "superactive" conformation sustaining cellular signaling and resulting in enhanced angiogenesis $[152,153,227]$. This may be particularly relevant to the clinical use of cilengitide, which has a short half-life of about two to four hours, and its concentration in the plasma fluctuates dramatically between injections, resulting in possible dual effects $[7,28]$. A further complication is suggested by the inability of Arg-Gly-Asp-based antagonists to disrupt $\alpha \mathrm{V} \beta 3$-ligand binding in contrast to allosteric antagonists [228]. Thus, allosteric antagonists may be more effective than competitive antagonists to interfere with ligand-occupied integrins. Also, it appears that ligand occupied integrins can still transduce survival signals, even in cells in suspension [59-61]. For example, treating cells with integrin ligand antagonists or expressing mutant integrins with impaired ligand-binding capacity did not prevent $\alpha \mathrm{V} \beta 3$ from promoting the CSC phenotype [95].

These observations raise the possibility that integrins disengaged from the ECM but occupied by natural ligands or high-affinity inhibitors may still signal and sustain cell survival. This hypothesis can be tested by either inhibiting residual integrin-dependent signaling (e.g., by using kinase inhibitors) in cells treated with integrin inhibitors, or by developing a novel class of integrin antagonists that block both cell adhesion and signaling. As the interaction between the cytoplasmic tails with cytoplasmic structural and signaling proteins is essential for both adhesion and signaling functions [229], this may open unexplored opportunities to develop a novel class of inhibitors. We previously showed that the expression of isolated $\beta$ integrin subunit cytoplasmic and transmembrane domains in adherent endothelial cells in vitro and in vivo caused massive cell detachment and death. The mechanisms involved competition for the binding of essential cytoplasmic adaptor proteins (e.g., talin) to engaged integrins (dominant negative effect), resulting in a 'mechanical uncoupling' of the integrins from cytoskeletal structures and signaling molecules [230-232]. Unfortunately, the effect was not integrin-specific: the expression of isolated $\beta 3$ or $\beta 1$ subunit cytoplasmic domain indiscriminately blocked both $\beta 3$ and $\beta 1$ functions. This was likely because interactions of cytoplasmic domains with key proteins of the adhesome are largely conserved across different integrins. Consistent with these 
observations, point mutations in the $\mathrm{Y747F}$ and $\mathrm{Y} 759 \mathrm{~F}$ of $\beta 3$ subunits inhibited tumor angiogenesis and tumor growth [233]. As the structure and molecular composition of the adhesion, as well as the molecular interactions controlling integrin function all have dramatically improved since [35,36], it may be worth revisiting the possibility of selectively inhibiting integrin function by interfering with the adhesome. For example, the deletion of kindlin-2 reduced endothelial sprouting, while ILK silencing reduced endothelial cell migration, tube formation, and tumor angiogenesis [234-236].

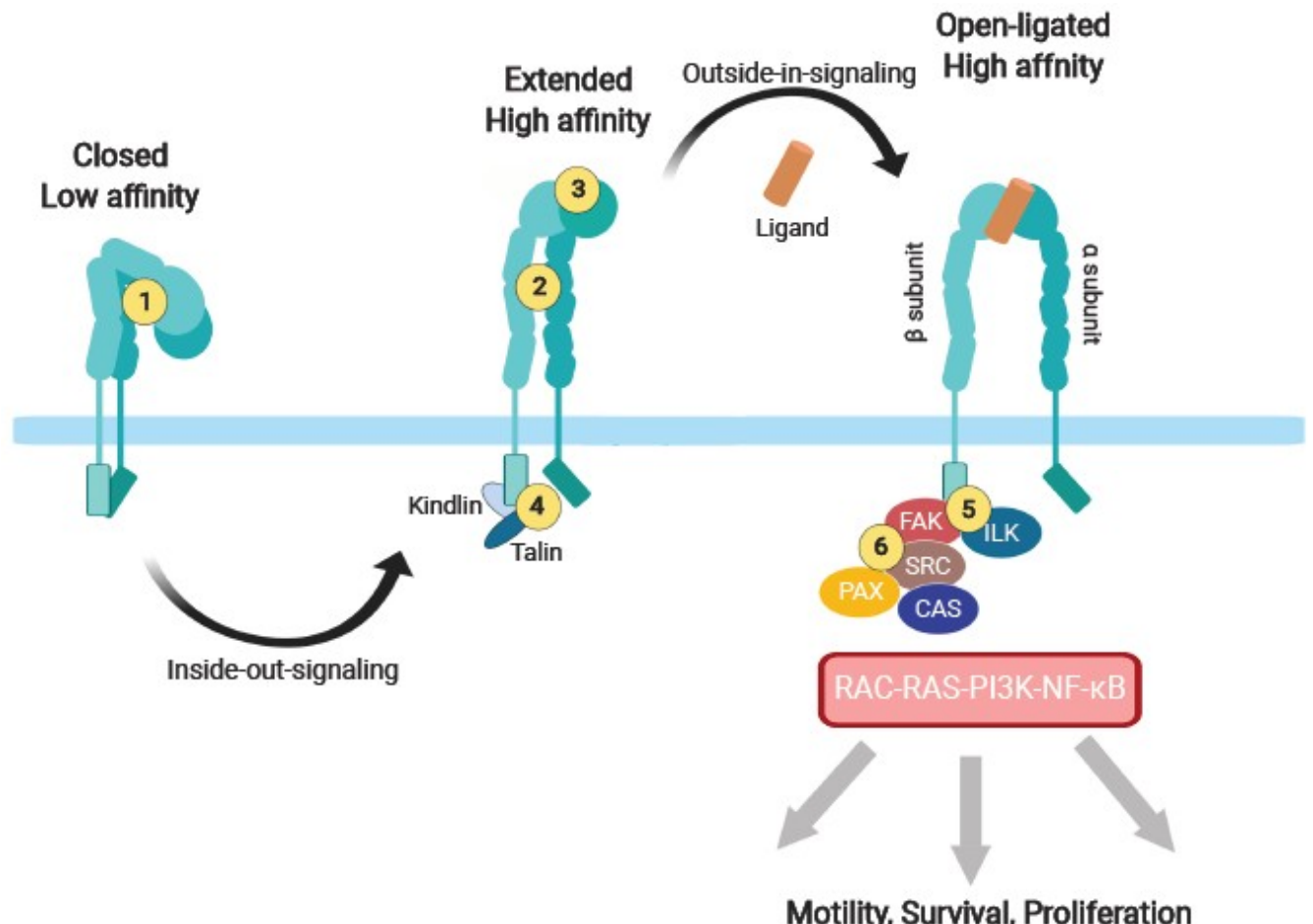

Figure 3. Alternative strategies to inhibit integrins. Current integrin inhibitors are mostly based on preventing ligand binding through direct competition or (allo)steric interference with the extracellular domains. However, some of these ligand-binding inhibitors may activate integrins and do not fully suppress integrin signaling. Alternative approaches to interfere with integrin function may be considered since integrin activation and signaling are complex events involving multiple and different steps. Strategies to consider include: 1, the retention of bent integrins in their low-affinity state; 2 , the prevention of full integrin extension and affinity maturation; and 3, irreversible preclusion of ligand binding by covalent modification of the binding pocket. The intracellular domains and the adhesome also provide additional opportunities, including: 4, interfering with kindlin/talin-mediated activation; 5 , the prevention of recruitments of signaling proteins of the adhesome (e.g., FAK) to the $\beta$ cytodomain; 6 , the prevention of adhesome maturation or induction of adhesome dissolution by interfering with protein-protein interactions.

\subsection{Did We Target the Wrong Biological Process(es)?}

A key rationale that fostered the development of integrin inhibitors as anti-cancer agents, in particular those targeting $\alpha \mathrm{V} \beta 3$, was their ability to suppress tumor angiogenesis in preclinical models [237]. As we have learned from clinical trials with numerous anti-angiogenic drugs, the suppression of tumor angiogenesis alone was revealed to be insufficient to effectively control tumor progression. Eventually, only a few anti-angiogenic drugs were approved for clinical use, and this was largely in combination with cytotoxic chemotherapy, in a limited number of advanced and metastatic cancers. Moderate outcome benefits were demonstrated in colorectal, kidney, and liver cancer, while the benefits in lung, breast, and ovarian cancer or glioblastoma were very modest or absent $[6,238]$. Thus, it could be that the effects of integrins' inhibition on the tumor vasculature did not translate into anti-tumor effects, not because 
of their inefficacy, but because of the complex relationship between tumor angiogenesis and tumor progression, and the ability of cancer cells to adapt and escape from anti-angiogenic therapies [163]. The combined targeting of several integrin receptors and other angiogenic pathways may be required to obtain significant anti-tumor effects.

Importantly, until today, we lacked an adequate biomarker to predict which patients are likely to benefit from anti-integrin treatment. While metabolic imaging and tissue analysis suggest that cilengitide reaches its target, there is no information about its effects on the tumor vasculature or tumor invasion in patients [7]. In the CENTRIC (Cilengitide, Temozolomide, and Radiation Therapy in Treating Patients With Newly Diagnosed Glioblastoma and Methylated Gene Promoter Status) trial (Methyl Guanine Methyl Transferase (MGMT) promoter methylated tumors), $\alpha \mathrm{V} \beta 3$ expression did not reveal any prognostic or predictive information, while in the CORE (Cilengitide, Temozolomide, and Radiation Therapy in Treating Patients With Newly Diagnosed Glioblastoma and Unmethylated Gene Promoter Status) trial (unmethylated tumors), higher tumor expression levels of $\alpha \mathrm{V} \beta 3$ were associated with slightly improved progression-free and overall survivals in patients treated with cilengitide [177]. Still, this puts doubt as to whether tissue integrin expression is a useful biomarker. The identification of biomarkers that are predictive of responses-or as a surrogate for target engagement and for monitoring the activity of integrin inhibitors-is needed before further clinical investigation is carried out.

The three main cancer cell-related processes that were considered as attractive targets for integrin inhibitors are cell proliferation, survival, and invasion [18,239]. However, impinging on cell proliferation and survival on cancer cells through integrin inhibition may be difficult to achieve, as fully transformed cells acquire cell-autonomous growth and survival capacities in the absence of extracellular cues through the activation of oncogenes and the inactivation of tumor suppressor genes [240]. The inhibition of invasion, which is a critical event in the metastatic cascade, seems more plausible to achieve. However, since patients treated with integrins inhibitors had advanced invasive or metastatic diseases, these potential benefits may be blunted. As metastasis represents a starting point for further seeding, one may nevertheless expect effects on further metastatic spreading [241,242]. However, it should also be noted that cancer cells can invade the ECM without the need for integrin engagement through ameboid movements, which obviously would represent an escape mechanism to integrin inhibition [35,56,57].

The microenvironment of most tumors is densely infiltrated with leucocytes and lymphocytes, which use integrins for their homing, migration, and local functions [243-245]. While targeting leucocyte integrins has been successful in the management of autoimmune diseases, it remains largely unexplored in cancer [35]. This is a potentially appealing strategy considering that the tumor microenvironment is rich in immunosuppressive cells (i.e., Regulatory T cells, Treg; Myeloid Derived Suppressor Cells, MDSC) and their inhibition boosts the immune response [246]. For example, antagonists of integrin $\alpha 4 \beta 1$ blocked the extravasation of monocytes into tumor tissue and prevented the monocyte macrophage colonization of tumors and tumor angiogenesis [247]. While attractive conceptually, a selective inhibition of Treg or MDSC recruitment may be difficult to achieve in practice. Immune and inflammatory cells in the tumor microenvironment (i.e., granulocytes, MDSC, monocytes, Dendritic Cells (DC) cells, T cell, B cells, Natural Killer (NK) cells) use overlapping integrins to home, extravasate, and migrate to the tumor microenvironment, namely $\alpha \mathrm{L} \beta 2, \alpha \mathrm{M} \beta 2$, $\alpha \mathrm{X} \beta 2, \alpha 4 \beta 1, \alpha 1 \beta 1, \alpha 2 \beta 1, \alpha \mathrm{V} \beta 3$, and $\alpha 5 \beta 1$. This overlapping pattern of expression and the targeting some of the integrins, most notably $\alpha 4$ and $\beta 2$, may cause severe unwanted effects such as viral and bacterial infections, as these integrins are critical to the physiological immune response, which significantly complicates such an approach [35].

A further cell population of the tumor microenvironment that may be considered to be targeted with integrins inhibitors is the CAF. CAF are well established to promote cancer progression through paracrine communication and remodeling of the $\mathrm{ECM}$, which is a process that is tightly dependent on integrins. Thus, inhibiting integrins on $\mathrm{CAF}$, in particular of the $\alpha \mathrm{V}$ and $\beta 1$ family, is likely to interfere 
with matrix deposition and remodeling, and indirectly to suppress matrix-dependent functions that normally promote tumor progression, in particular survival and invasion [31,32].

In addition to inhibiting integrin function to impinge on cancer-associated events, integrins may serve as targets to deliver cytotoxic drugs to tumors, for instance by using antibody-drug conjugates (ADCs). While this approach is not fully novel, it may pay off in some cancers, and may be combined with diagnostic procedures (theragnostic).

\subsection{Did We Use the Wrong Preclinical Models?}

Preclinical tumor models used for drug testing are typically based on monitoring drug activity on primary tumor growth and possibly on their metastatic dissemination $[248,249]$. These conditions do not reflect the clinical situation in which systemic therapy is either used as adjuvant therapy to eliminate microscopic or minimal residual disease and/or already disseminated cancer cells, or as palliative therapies in patients with advanced and metastatic disease. Thus, most preclinical models do not represent the actual clinical situation of patients eventually receiving the tested drug at the advanced/metastatic stages [249]. This is a potentially confounding factor that may lead to overestimating the therapeutic effects of the tested drugs. In addition, transplantable tumors based on cell lines do not fully recapitulate the biological and molecular feature of the corresponding human tumors, and in the case of xenografts, the host is immunodeficient, thereby depriving the tumor microenvironment of important immunological functions. As this is a general problem in drug testing, there is an urgent need to align preclinical models with the relevant clinical situation. Suitable models should include orthotopic primary tumor growth, spontaneous metastasis formation, primary tumor removal, and the treatment of metastatic disease.

\subsection{Did We Perform the Wrong Clinical Trials?}

A number of clinical trials were performed for over a decade, investigating either competitive peptide-based inhibitors or monoclonal antibodies targeting specific integrins (Table 2). The largest trial portfolio was for cilengitide, which is a cyclic inhibitor targeting $\alpha \mathrm{V} \beta 3$ and $\alpha \mathrm{V} \beta 5$ integrins. Trials were well planned, and many were designed as randomized phase 2 trials aiming at identifying the optimal dose or dosing regimen and activity signal seeking. Nevertheless, with a short half-life of only a few hours, a twice-weekly infusion schedule may not have been an optimal choice, while drug solubility limited the options of a continuous infusion schedule. The only partial penetration through the blood-brain barrier is another limitation in particular when treating primary brain tumors. The cilengitide development program also illustrates the limitations of randomized phase II trials that cannot replace formal comparative phase III trials. Furthermore, a more critical interpretation of phase II results and the integration of correlative endpoints is warranted if this design is to determine the fate of an investigational agent. Predefined stringent criteria for "success" and "go/no go" decisions should be determined at the onset of phase II trials.

Most trials targeting integrins to date are similar in design, and have repeatedly focused on the same clinically defined tumor entities. Although some of the trials are aimed at enriching a certain molecular subgroup (e.g., MGMT methylation in glioblastoma trials, mutated Kirsten RAS (KRAS) in colorectal cancer), these markers are of important prognostic value of the disease of interest. However, they have no mechanistic relationship to integrins as a treatment target.

\section{Conclusions}

In spite of compelling experimental results demonstrating that integrins contribute to cancer progression and that their inhibition has therapeutic effects, clinical trials with $\alpha \mathrm{V} \beta 3 / \alpha \mathrm{V} \beta 5$ and $\alpha 5 \beta 1$ integrin inhibitors have globally failed to demonstrate therapeutic benefits, and no inhibitors has been registered as anti-cancer drug. However, therapy strategies have focused so far solely on integrins on tumor cells and vascular cells. Consequently, new approaches targeting integrins in other cells of the tumor microenvironment, e.g., cancer-associated fibroblasts and inflammatory/immune cells, 
are necessary and should be considered. Additionally, the pharmacological properties of the integrin inhibitor and the heterogeneity and redundancies of integrin functions require further understanding before proceeding with future investigation of novel integrin-targeting agents in the clinic. We conclude that integrins remain a valid target for cancer therapy, but novel preclinical models and translational studies focusing on the tumor microenvironment are needed.

Author Contributions: Conceptualization and writing, B.A.-P., R.S. and C.R. Funding acquisition for laboratory work, C.R.

Funding: Research in our laboratory is funded by the Swiss National Sciences Foundation (31003A_159824/1; 31003A_179248/1), the Swiss Cancer League (KSF3513-08-2014; KSF-4400-02-2018), NCCR Molecular Oncology, NCCR Bio-Inspired materials, the Medic Foundation, the Sassella Stiftung, the 3R foundation, and the European Union under the auspices of the FP7 collaborative project TuMIC, contract no. HEALTH-F2-2008-201662.

Acknowledgments: We apologize for not being able to cite all published work relevant to this topic due to selective focus of the article and space limitation.

Conflicts of Interest: The authors declare no conflict of interest.

\section{References}

1. Hemler, M.E. VLA proteins in the integrin family: Structures, functions, and their role on leukocytes. Annu. Rev. Immunol. 1990, 8, 365-400. [CrossRef] [PubMed]

2. Ruoslahti, E. Fibronectin and its integrin receptors in cancer. Adv. Cancer Res. 1999, 76, 1-20. [PubMed]

3. Hynes, R.O. Integrins: Bidirectional, allosteric signaling machines. Cell 2002, 110, 673-687. [CrossRef]

4. Luo, B.H.; Carman, C.V.; Springer, T.A. Structural basis of integrin regulation and signaling. Annu. Rev. Immunol. 2007, 25, 619-647. [CrossRef] [PubMed]

5. Curley, G.P.; Blum, H.; Humphries, M.J. Integrin antagonists. Cell Mol. Life Sci. 1999, 56, 427-441. [CrossRef] [PubMed]

6. Stupp, R.; Hegi, M.E.; Gorlia, T.; Erridge, S.C.; Perry, J.; Hong, Y.K.; Aldape, K.D.; Lhermitte, B.; Pietsch, T.; Grujicic, D.; et al. Cilengitide combined with standard treatment for patients with newly diagnosed glioblastoma with methylated MGMT promoter (CENTRIC EORTC 26071-22072 study): A multicentre, randomised, open-label, phase 3 trial. Lancet Oncol. 2014, 15, 1100-1108. [CrossRef]

7. Chinot, O.L. Cilengitide in glioblastoma: When did it fail? Lancet Oncol. 2014, 15, 1044-1045. [CrossRef]

8. Takada, Y.; Xiaojing, X.; Scott, S. The integrins. Genome Biol. 2007, 8, 215. [CrossRef]

9. Ruegg, C.; Alghisi, G.C. Vascular integrins: Therapeutic and imaging targets of tumor angiogenesis. Recent Results Cancer Res. 2010, 180, 83-101. [CrossRef]

10. Lau, L.F. Cell surface receptors for CCN proteins. J. Cell Commun. Signal. 2016, 10, 121-127. [CrossRef]

11. Liddington, R.C. Structural aspects of integrins. Adv. Exp. Med. Biol. 2014, 819, 111-126. [CrossRef] [PubMed]

12. Humphries, J.D.; Byron, A.; Humphries, M.J. Integrin ligands at a glance. J. Cell Sci. 2006, 119, 3901-3903. [CrossRef] [PubMed]

13. Bianconi, D.; Unseld, M.; Prager, G.W. Integrins in the Spotlight of Cancer. Int. J. Mol. Sci. $2016,2037$. [CrossRef] [PubMed]

14. Sun, Z.; Costell, M.; Fassler, R. Integrin activation by talin, kindlin and mechanical forces. Nat. Cell Biol. 2019, 21, 25-31. [CrossRef] [PubMed]

15. Ruegg, C.; Dormond, O.; Mariotti, A. Endothelial cell integrins and COX-2: Mediators and therapeutic targets of tumor angiogenesis. Biochim. Biophys. Acta 2004, 1654, 51-67. [CrossRef] [PubMed]

16. Moschos, S.J.; Drogowski, L.M.; Reppert, S.L.; Kirkwood, J.M. Integrins and cancer. Oncology 2007, 21, 13-20. [PubMed]

17. Wenke, A.K.; Kjellman, C.; Lundgren-Akerlund, E.; Uhlmann, C.; Haass, N.K.; Herlyn, M.; Bosserhoff, A.K. Expression of integrin alpha10 is induced in malignant melanoma. Cell Oncol. 2007, 29, 373-386. [CrossRef]

18. Makrilia, N.; Kollias, A.; Manolopoulos, L.; Syrigos, K. Cell adhesion molecules: Role and clinical significance in cancer. Cancer Investig. 2009, 27, 1023-1037. [CrossRef] [PubMed]

19. Desgrosellier, J.S.; Cheresh, D.A. Integrins in cancer: Biological implications and therapeutic opportunities. Nat. Rev. Cancer 2010, 10, 9. [CrossRef] 
20. Ganguly, K.K.; Pal, S.; Moulik, S.; Chatterjee, A. Integrins and metastasis. Cell Adh. Migr. 2013, 7, $251-261$. [CrossRef]

21. Katoh, D.; Nagaharu, K.; Shimojo, N.; Hanamura, N.; Yamashita, M.; Kozuka, Y.; Imanaka-Yoshida, K.; Yoshida, T. Binding of alphavbeta1 and alphavbeta6 integrins to tenascin-C induces epithelial-mesenchymal transition-like change of breast cancer cells. Oncogenesis 2013, 2, e65. [CrossRef] [PubMed]

22. Seguin, L.; Desgrosellier, J.S.; Weis, S.M.; Cheresh, D.A. Integrins and cancer: Regulators of cancer stemness, metastasis, and drug resistance. Trends Cell Biol. 2015, 25, 234-240. [CrossRef] [PubMed]

23. Hamidi, H.; Pietila, M.; Ivaska, J. The complexity of integrins in cancer and new scopes for therapeutic targeting. Br. J. Cancer 2016, 115, 1017-1023. [CrossRef] [PubMed]

24. Ryu, J.; Koh, Y.; Park, H.; Kim, D.Y.; Kim, D.C.; Byun, J.M.; Lee, H.J.; Yoon, S.S. Highly Expressed Integrin-alpha8 Induces Epithelial to Mesenchymal Transition-Like Features in Multiple Myeloma with Early Relapse. Mol. Cells 2016, 39, 898-908. [CrossRef] [PubMed]

25. Khan, Z.; Marshall, J.F. The role of integrins in TGFbeta activation in the tumour stroma. Cell Tissue Res. 2016, 365, 657-673. [CrossRef] [PubMed]

26. Ming, X.Y.; Fu, L.; Zhang, L.Y.; Qin, Y.R.; Cao, T.T.; Chan, K.W.; Ma, S.; Xie, D.; Guan, X.Y. Integrin alpha7 is a functional cancer stem cell surface marker in oesophageal squamous cell carcinoma. Nat. Commun. 2016, 7, 13568. [CrossRef] [PubMed]

27. Haas, T.L.; Sciuto, M.R.; Brunetto, L.; Valvo, C.; Signore, M.; Fiori, M.E.; di Martino, S.; Giannetti, S.; Morgante, L.; Boe, A.; et al. Integrin alpha7 Is a Functional Marker and Potential Therapeutic Target in Glioblastoma. Cell Stem Cell 2017, 21, 35-50.e9. [CrossRef] [PubMed]

28. Nieberler, M.; Reuning, U.; Reichart, F.; Notni, J.; Wester, H.J.; Schwaiger, M.; Weinmuller, M.; Rader, A.; Steiger, K.; Kessler, H. Exploring the Role of RGD-Recognizing Integrins in Cancer. Cancers 2017, 116. [CrossRef]

29. Okada, T.; Singer, S. Integrin-alpha10 drives tumorigenesis in sarcoma. Oncoscience 2017, 4, 31-32. [CrossRef]

30. Hamidi, H.; Ivaska, J. Every step of the way: Integrins in cancer progression and metastasis. Nat. Rev. Cancer 2018, 18, 533-548. [CrossRef]

31. DiPersio, C.M.; Van De Water, L. Integrin Regulation of CAF Differentiation and Function. Cancers $2019,715$. [CrossRef] [PubMed]

32. Jang, I.; Beningo, K.A. Integrins, CAFs and Mechanical Forces in the Progression of Cancer. Cancers $2019,721$. [CrossRef] [PubMed]

33. Jahed, Z.; Shams, H.; Mehrbod, M.; Mofrad, M.R. Mechanotransduction pathways linking the extracellular matrix to the nucleus. Int. Rev. Cell Mol. Biol. 2014, 310, 171-220. [CrossRef] [PubMed]

34. Schwartz, M.A.; Ginsberg, M.H. Networks and crosstalk: Integrin signalling spreads. Nat. Cell Biol. 2002, 4, E65-E68. [CrossRef] [PubMed]

35. Vicente-Manzanares, M.; Sanchez-Madrid, F. Targeting the integrin interactome in human disease. Curr. Opin. Cell Biol. 2018, 55, 17-23. [CrossRef]

36. Horton, E.R.; Astudillo, P.; Humphries, M.J.; Humphries, J.D. Mechanosensitivity of integrin adhesion complexes: Role of the consensus adhesome. Exp. Cell Res. 2016, 343, 7-13. [CrossRef] [PubMed]

37. Cooper, J.; Giancotti, F.G. Integrin Signaling in Cancer: Mechanotransduction, Stemness, Epithelial Plasticity, and Therapeutic Resistance. Cancer Cell 2019, 35, 347-367. [CrossRef] [PubMed]

38. Wee, P.; Wang, Z. Epidermal Growth Factor Receptor Cell Proliferation Signaling Pathways. Cancers $2017,52$. [CrossRef]

39. Montor, W.R.; Salas, A.; Melo, F.H.M. Receptor tyrosine kinases and downstream pathways as druggable targets for cancer treatment: The current arsenal of inhibitors. Mol. Cancer 2018, 17, 55. [CrossRef]

40. Tang, F.; Wang, Y.; Hemmings, B.A.; Ruegg, C.; Xue, G. PKB/Akt-dependent regulation of inflammation in cancer. Semin. Cancer Biol. 2018, 48, 62-69. [CrossRef]

41. Yaeger, R.; Corcoran, R.B. Targeting Alterations in the RAF-MEK Pathway. Cancer Discov. 2019, 9, 329-341. [CrossRef] [PubMed]

42. Thorpe, L.M.; Yuzugullu, H.; Zhao, J.J. PI3K in cancer: Divergent roles of isoforms, modes of activation and therapeutic targeting. Nat. Rev. Cancer 2015, 15, 7-24. [CrossRef] [PubMed]

43. Pignatelli, M.; Stamp, G. Integrins in tumour development and spread. Cancer Surv. 1995, 24, $113-127$. [PubMed] 
44. Maschler, S.; Wirl, G.; Spring, H.; Bredow, D.v.; Sordat, I.; Beug, H.; Reichmann, E. Tumor cell invasiveness correlates with changes in integrin expression and localization. Oncogene 2005, 24, 2032-2041. [CrossRef] [PubMed]

45. Sokeland, G.; Schumacher, U. The functional role of integrins during intra- and extravasation within the metastatic cascade. Mol. Cancer 2019, 18, 12. [CrossRef] [PubMed]

46. Brabletz, T.; Kalluri, R.; Nieto, M.A.; Weinberg, R.A. EMT in cancer. Nat. Rev. Cancer 2018, 18, 128-134. [CrossRef]

47. Kim, Y.; Kugler, M.C.; Wei, Y.; Kim, K.K.; Li, X.; Brumwell, A.N.; Chapman, H.A. Integrin alpha3beta1dependent beta-catenin phosphorylation links epithelial Smad signaling to cell contacts. J. Cell Biol. 2009, 184, 309-322. [CrossRef]

48. Morrison, C.D.; Parvani, J.G.; Schiemann, W.P. The relevance of the TGF-beta Paradox to EMT-MET programs. Cancer Lett. 2013, 341, 30-40. [CrossRef]

49. Yang, X.; Pursell, B.; Lu, S.; Chang, T.K.; Mercurio, A.M. Regulation of beta 4-integrin expression by epigenetic modifications in the mammary gland and during the epithelial-to-mesenchymal transition. J. Cell Sci. 2009, 122, 2473-2480. [CrossRef]

50. Agajanian, M.; Runa, F.; Kelber, J.A. Identification of a PEAK1/ZEB1 signaling axis during TGFbeta/ fibronectin-induced EMT in breast cancer. Biochem. Biophys. Res. Commun. 2015, 465, 606-612. [CrossRef]

51. Nam, E.H.; Lee, Y.; Moon, B.; Lee, J.W.; Kim, S. Twist1 and AP-1 cooperatively upregulate integrin alpha5 expression to induce invasion and the epithelial-mesenchymal transition. Carcinogenesis 2015, 36, 327-337. [CrossRef] [PubMed]

52. Gritsenko, P.G.; Ilina, O.; Friedl, P. Interstitial guidance of cancer invasion. J. Pathol. 2012, 226, 185-199. [CrossRef] [PubMed]

53. Ashour, A.A.; Gurbuz, N.; Alpay, S.N.; Abdel-Aziz, A.A.; Mansour, A.M.; Huo, L.; Ozpolat, B. Elongation factor-2 kinase regulates TG2/beta1 integrin/Src/uPAR pathway and epithelial-mesenchymal transition mediating pancreatic cancer cells invasion. J. Cell Mol. Med. 2014, 18, 2235-2251. [CrossRef] [PubMed]

54. Rolli, M.; Fransvea, E.; Pilch, J.; Saven, A.; Felding-Habermann, B. Activated integrin alphavbeta3 cooperates with metalloproteinase MMP-9 in regulating migration of metastatic breast cancer cells. Proc. Natl. Acad. Sci. USA 2003, 100, 9482-9487. [CrossRef] [PubMed]

55. Wolf, K.; Wu, Y.I.; Liu, Y.; Geiger, J.; Tam, E.; Overall, C.; Stack, M.S.; Friedl, P. Multi-step pericellular proteolysis controls the transition from individual to collective cancer cell invasion. Nat. Cell Biol. 2007, 9, 893-904. [CrossRef] [PubMed]

56. Friedl, P.; Wolf, K. Tumour-cell invasion and migration: Diversity and escape mechanisms. Nat. Rev. Cancer 2003, 3, 362-374. [CrossRef] [PubMed]

57. Schmidt, S.; Friedl, P. Interstitial cell migration: Integrin-dependent and alternative adhesion mechanisms. Cell Tissue Res. 2010, 339, 83-92. [CrossRef] [PubMed]

58. Paoli, P.; Giannoni, E.; Chiarugi, P. Anoikis molecular pathways and its role in cancer progression. Biochim. Biophys. Acta 2013, 1833, 3481-3498. [CrossRef]

59. Alanko, J.; Mai, A.; Jacquemet, G.; Schauer, K.; Kaukonen, R.; Saari, M.; Goud, B.; Ivaska, J. Integrin endosomal signalling suppresses anoikis. Nat. Cell Biol. 2015, 17, 1412-1421. [CrossRef]

60. Desgrosellier, J.S.; Barnes, L.A.; Shields, D.J.; Huang, M.; Lau, S.K.; Prevost, N.; Tarin, D.; Shattil, S.J.; Cheresh, D.A. An integrin alpha(v)beta(3)-c-Src oncogenic unit promotes anchorage-independence and tumor progression. Nat. Med. 2009, 15, 1163-1169. [CrossRef]

61. Huang, Y.T.; Lan, Q.; Lorusso, G.; Duffey, N.; Ruegg, C. The matricellular protein CYR61 promotes breast cancer lung metastasis by facilitating tumor cell extravasation and suppressing anoikis. Oncotarget 2017, 8, 9200-9215. [CrossRef] [PubMed]

62. Barrow-McGee, R.; Kishi, N.; Joffre, C.; Menard, L.; Hervieu, A.; Bakhouche, B.A.; Noval, A.J.; Mai, A.; Guzman, C.; Robbez-Masson, L.; et al. Corrigendum: Beta 1-integrin-c-Met cooperation reveals an inside-in survival signalling on autophagy-related endomembranes. Nat. Commun. 2016, 7, 12392. [CrossRef] [PubMed]

63. Mitra, A.K.; Sawada, K.; Tiwari, P.; Mui, K.; Gwin, K.; Lengyel, E. Ligand-independent activation of c-Met by fibronectin and alpha(5)beta(1)-integrin regulates ovarian cancer invasion and metastasis. Oncogene 2011, 30 , 1566-1576. [CrossRef] [PubMed] 
64. Trusolino, L.; Bertotti, A.; Comoglio, P.M. A signaling adapter function for alpha6beta4 integrin in the control of HGF-dependent invasive growth. Cell 2001, 107, 643-654. [CrossRef]

65. Mossmann, D.; Park, S.; Hall, M.N. mTOR signalling and cellular metabolism are mutual determinants in cancer. Nat. Rev. Cancer 2018, 18, 744-757. [CrossRef] [PubMed]

66. Sullivan, L.B.; Gui, D.Y.; Vander Heiden, M.G. Altered metabolite levels in cancer: Implications for tumour biology and cancer therapy. Nat. Rev. Cancer 2016, 16, 680-693. [CrossRef] [PubMed]

67. Ata, R.; Antonescu, C.N. Integrins and Cell Metabolism: An Intimate Relationship Impacting Cancer. Int. J. Mol. Sci. 2017, 189. [CrossRef] [PubMed]

68. Rainero, E. Extracellular matrix internalization links nutrient signalling to invasive migration. Int. J. Exp. Pathol. 2018, 99, 4-9. [CrossRef] [PubMed]

69. Zhao, Z.; Rahman, M.A.; Chen, Z.G.; Shin, D.M. Multiple biological functions of Twist1 in various cancers. Oncotarget 2017, 8, 20380-20393. [CrossRef]

70. Huang, R.; Zong, X. Aberrant cancer metabolism in epithelial-mesenchymal transition and cancer metastasis: Mechanisms in cancer progression. Crit. Rev. Oncol. Hematol. 2017, 115, 13-22. [CrossRef]

71. Shaul, Y.D.; Freinkman, E.; Comb, W.C.; Cantor, J.R.; Tam, W.L.; Thiru, P.; Kim, D.; Kanarek, N.; Pacold, M.E.; Chen, W.W.; et al. Dihydropyrimidine accumulation is required for the epithelial-mesenchymal transition. Cell 2014, 158, 1094-1109. [CrossRef] [PubMed]

72. Vlahakis, A.; Debnath, J. The Interconnections between Autophagy and Integrin-Mediated Cell Adhesion. J. Mol. Biol. 2017, 429, 515-530. [CrossRef] [PubMed]

73. Sun, Z.; Schwenzer, A.; Rupp, T.; Murdamoothoo, D.; Vegliante, R.; Lefebvre, O.; Klein, A.; Hussenet, T.; Orend, G. Tenascin-C Promotes Tumor Cell Migration and Metastasis through Integrin alpha9beta1-Mediated YAP Inhibition. Cancer Res. 2018, 78, 950-961. [CrossRef] [PubMed]

74. Serrano, I.; McDonald, P.C.; Lock, F.; Muller, W.J.; Dedhar, S. Inactivation of the Hippo tumour suppressor pathway by integrin-linked kinase. Nat. Commun. 2013, 4, 2976. [CrossRef] [PubMed]

75. Santinon, G.; Pocaterra, A.; Dupont, S. Control of YAP/TAZ Activity by Metabolic and Nutrient-Sensing Pathways. Trends Cell Biol. 2016, 26, 289-299. [CrossRef] [PubMed]

76. Moroishi, T.; Hansen, C.G.; Guan, K.L. The emerging roles of YAP and TAZ in cancer. Nat. Rev. Cancer 2015, 15, 73-79. [CrossRef] [PubMed]

77. Lopez-Lago, M.A.; Okada, T.; Murillo, M.M.; Socci, N.; Giancotti, F.G. Loss of the tumor suppressor gene NF2, encoding merlin, constitutively activates integrin-dependent mTORC1 signaling. Mol. Cell Biol. 2009, 29, 4235-4249. [CrossRef]

78. Yang, L.; Hou, Y.; Yuan, J.; Tang, S.; Zhang, H.; Zhu, Q.; Du, Y.E.; Zhou, M.; Wen, S.; Xu, L.; et al. Twist promotes reprogramming of glucose metabolism in breast cancer cells through PI3K/AKT and p53 signaling pathways. Oncotarget 2015, 6, 25755-25769. [CrossRef] [PubMed]

79. Schafer, Z.T.; Grassian, A.R.; Song, L.; Jiang, Z.; Gerhart-Hines, Z.; Irie, H.Y.; Gao, S.; Puigserver, P.; Brugge, J.S. Antioxidant and oncogene rescue of metabolic defects caused by loss of matrix attachment. Nature 2009, 461, 109-113. [CrossRef]

80. Gallagher, S.M.; Castorino, J.J.; Philp, N.J. Interaction of monocarboxylate transporter 4 with beta1-integrin and its role in cell migration. Am. J. Physiol. Cell Physiol. 2009, 296, C414-C421. [CrossRef]

81. Pinheiro, C.; Longatto-Filho, A.; Azevedo-Silva, J.; Casal, M.; Schmitt, F.C.; Baltazar, F. Role of monocarboxylate transporters in human cancers: State of the art. J. Bioenerg. Biomembr. 2012, 44, 127-139. [CrossRef] [PubMed]

82. Visvader, J.E.; Lindeman, G.J. Cancer stem cells: Current status and evolving complexities. Cell Stem Cell 2012, 10, 717-728. [CrossRef] [PubMed]

83. Medema, J.P. Cancer stem cells: The challenges ahead. Nat. Cell Biol. 2013, 15, 338. [CrossRef] [PubMed]

84. Malanchi, I.; Santamaria-Martínez, A.; Susanto, E.; Peng, H.; Lehr, H.-A.; Delaloye, J.-F.; Huelsken, J. Interactions between cancer stem cells and their niche govern metastatic colonization. Nature 2011, 481, 85. [CrossRef] [PubMed]

85. Oskarsson, T.; Acharyya, S.; Zhang, X.H.F.; Vanharanta, S.; Tavazoie, S.F.; Morris, P.G.; Downey, R.J.; Manova-Todorova, K.; Brogi, E.; Massagué, J. Breast cancer cells produce tenascin C as a metastatic niche component to colonize the lungs. Nat. Med. 2011, 17, 867. [CrossRef] [PubMed]

86. Taddei, I.; Deugnier, M.-A.; Faraldo, M.M.; Petit, V.; Bouvard, D.; Medina, D.; Fässler, R.; Thiery, J.P.; Glukhova, M.A. $\beta 1$ Integrin deletion from the basal compartment of the mammary epithelium affects stem cells. Nat. Cell Biol. 2008, 10, 716. [CrossRef] [PubMed] 
87. Martin, T.A.; Jiang, W.G. Evaluation of the expression of stem cell markers in human breast cancer reveals a correlation with clinical progression and metastatic disease in ductal carcinoma. Oncol. Rep. 2014, 31, 262-272. [CrossRef] [PubMed]

88. Hoogland, A.M.; Verhoef, E.I.; Roobol, M.J.; Schroder, F.H.; Wildhagen, M.F.; van der Kwast, T.H.; Jenster, G.; van Leenders, G.J. Validation of stem cell markers in clinical prostate cancer: alpha6-integrin is predictive for non-aggressive disease. Prostate 2014, 74, 488-496. [CrossRef]

89. Haraguchi, N.; Ishii, H.; Mimori, K.; Ohta, K.; Uemura, M.; Nishimura, J.; Hata, T.; Takemasa, I.; Mizushima, T.; Yamamoto, H.; et al. CD49f-positive cell population efficiently enriches colon cancer-initiating cells. Int. J. Oncol. 2013, 43, 425-430. [CrossRef]

90. Lathia, J.D.; Gallagher, J.; Heddleston, J.M.; Wang, J.; Eyler, C.E.; Macswords, J.; Wu, Q.; Vasanji, A.; McLendon, R.E.; Hjelmeland, A.B.; et al. Integrin alpha 6 regulates glioblastoma stem cells. Cell Stem Cell 2010, 6, 421-432. [CrossRef]

91. Zheng, Y.; de la Cruz, C.C.; Sayles, L.C.; Alleyne-Chin, C.; Vaka, D.; Knaak, T.D.; Bigos, M.; Xu, Y.; Hoang, C.D.; Shrager, J.B.; et al. A rare population of CD24(+)ITGB4(+)Notch(hi) cells drives tumor propagation in NSCLC and requires Notch3 for self-renewal. Cancer Cell 2013, 24, 59-74. [CrossRef] [PubMed]

92. Fernandez-Zapico, M.E. GLI1 finds a new role in cancer stem cell biology. Embo Mol. Med. 2013, 5, 483-485. [CrossRef]

93. Goel, H.L.; Gritsko, T.; Pursell, B.; Chang, C.; Shultz, L.D.; Greiner, D.L.; Norum, J.H.; Toftgard, R.; Shaw, L.M.; Mercurio, A.M. Regulated splicing of the alpha6 integrin cytoplasmic domain determines the fate of breast cancer stem cells. Cell Rep. 2014, 7, 747-761. [CrossRef]

94. Lo, P.K.; Kanojia, D.; Liu, X.; Singh, U.P.; Berger, F.G.; Wang, Q.; Chen, H. CD49f and CD61 identify Her2/neu-induced mammary tumor-initiating cells that are potentially derived from luminal progenitors and maintained by the integrin-TGF $\beta$ signaling. Oncogene 2011, 31, 2614. [CrossRef] [PubMed]

95. Seguin, L.; Kato, S.; Franovic, A.; Camargo, M.F.; Lesperance, J.; Elliott, K.C.; Yebra, M.; Mielgo, A.; Lowy, A.M.; Husain, H.; et al. An integrin $\beta 3-$ KRAS-RalB complex drives tumour stemness and resistance to EGFR inhibition. Nat. Cell Biol. 2014, 16, 457. [CrossRef]

96. Asselin-Labat, M.-L.; Sutherland, K.D.; Barker, H.; Thomas, R.; Shackleton, M.; Forrest, N.C.; Hartley, L.; Robb, L.; Grosveld, F.G.; van der Wees, J.; et al. Gata-3 is an essential regulator of mammary-gland morphogenesis and luminal-cell differentiation. Nat. Cell Biol. 2006, 9, 201. [CrossRef]

97. Desgrosellier, J.S.; Lesperance, J.; Seguin, L.; Gozo, M.; Kato, S.; Franovic, A.; Yebra, M.; Shattil, S.J.; Cheresh, D.A. Integrin alphavbeta3 drives slug activation and stemness in the pregnant and neoplastic mammary gland. Dev. Cell 2014, 30, 295-308. [CrossRef]

98. Damiano, J.S. Integrins as novel drug targets for overcoming innate drug resistance. Curr. Cancer Drug Targets 2002, 2, 37-43. [CrossRef] [PubMed]

99. Eke, I.; Deuse, Y.; Hehlgans, S.; Gurtner, K.; Krause, M.; Baumann, M.; Shevchenko, A.; Sandfort, V.; Cordes, N. beta(1)Integrin/FAK/cortactin signaling is essential for human head and neck cancer resistance to radiotherapy. J. Clin. Investig. 2012, 122, 1529-1540. [CrossRef] [PubMed]

100. Huang, C.; Park, C.C.; Hilsenbeck, S.G.; Ward, R.; Rimawi, M.F.; Wang, Y.C.; Shou, J.; Bissell, M.J.; Osborne, C.K.; Schiff, R. beta1 integrin mediates an alternative survival pathway in breast cancer cells resistant to lapatinib. Breast Cancer Res. 2011, 13, R84. [CrossRef] [PubMed]

101. Kanda, R.; Kawahara, A.; Watari, K.; Murakami, Y.; Sonoda, K.; Maeda, M.; Fujita, H.; Kage, M.; Uramoto, H.; Costa, C.; et al. Erlotinib resistance in lung cancer cells mediated by integrin beta1/Src/Akt-driven bypass signaling. Cancer Res. 2013, 73, 6243-6253. [CrossRef] [PubMed]

102. Jinushi, M.; Chiba, S.; Baghdadi, M.; Kinoshita, I.; Dosaka-Akita, H.; Ito, K.; Yoshiyama, H.; Yagita, H.; Uede, T.; Takaoka, A. ATM-mediated DNA damage signals mediate immune escape through integrin-alphavbeta3-dependent mechanisms. Cancer Res. 2012, 72, 56-65. [CrossRef] [PubMed]

103. Mulgrew, K.; Kinneer, K.; Yao, X.T.; Ward, B.K.; Damschroder, M.M.; Walsh, B.; Mao, S.Y.; Gao, C.; Kiener, P.A.; Coats, S.; et al. Direct targeting of alphavbeta3 integrin on tumor cells with a monoclonal antibody, Abegrin. Mol. Cancer 2006, 5, 3122-3129. [CrossRef] [PubMed]

104. Lambert, A.W.; Pattabiraman, D.R.; Weinberg, R.A. Emerging Biological Principles of Metastasis. Cell 2017, 168, 670-691. [CrossRef] [PubMed]

105. Psaila, B.; Lyden, D. The metastatic niche: Adapting the foreign soil. Nat. Rev. Cancer 2009, 9, $285-293$. [CrossRef] [PubMed] 
106. Sleeman, J.P.; Christofori, G.; Fodde, R.; Collard, J.G.; Berx, G.; Decraene, C.; Ruegg, C. Concepts of metastasis in flux: The stromal progression model. Semin. Cancer Biol. 2012, 22, 174-186. [CrossRef] [PubMed]

107. Erler, J.T.; Bennewith, K.L.; Cox, T.R.; Lang, G.; Bird, D.; Koong, A.; Le, Q.T.; Giaccia, A.J. Hypoxia-induced lysyl oxidase is a critical mediator of bone marrow cell recruitment to form the premetastatic niche. Cancer Cell 2009, 15, 35-44. [CrossRef] [PubMed]

108. Cox, T.R.; Rumney, R.M.H.; Schoof, E.M.; Perryman, L.; Hoye, A.M.; Agrawal, A.; Bird, D.; Latif, N.A.; Forrest, H.; Evans, H.R.; et al. The hypoxic cancer secretome induces pre-metastatic bone lesions through lysyl oxidase. Nature 2015, 522, 106-110. [CrossRef]

109. Zhang, H.; Wong, C.C.; Wei, H.; Gilkes, D.M.; Korangath, P.; Chaturvedi, P.; Schito, L.; Chen, J.; Krishnamachary, B.; Winnard, P.T., Jr.; et al. HIF-1-dependent expression of angiopoietin-like 4 and L1CAM mediates vascular metastasis of hypoxic breast cancer cells to the lungs. Oncogene 2012, 31, 1757-1770. [CrossRef] [PubMed]

110. Wong, C.C.; Gilkes, D.M.; Zhang, H.; Chen, J.; Wei, H.; Chaturvedi, P.; Fraley, S.I.; Wong, C.M.; Khoo, U.S.; $\mathrm{Ng}$, I.O.; et al. Hypoxia-inducible factor 1 is a master regulator of breast cancer metastatic niche formation. Proc. Natl. Acad. Sci. USA 2011, 108, 16369-16374. [CrossRef]

111. Hiratsuka, S.; Watanabe, A.; Sakurai, Y.; Akashi-Takamura, S.; Ishibashi, S.; Miyake, K.; Shibuya, M.; Akira, S.; Aburatani, H.; Maru, Y. The S100A8-serum amyloid A3-TLR4 paracrine cascade establishes a pre-metastatic phase. Nat. Cell Biol. 2008, 10, 1349-1355. [CrossRef] [PubMed]

112. Kaplan, R.N.; Riba, R.D.; Zacharoulis, S.; Bramley, A.H.; Vincent, L.; Costa, C.; MacDonald, D.D.; Jin, D.K.; Shido, K.; Kerns, S.A.; et al. VEGFR1-positive haematopoietic bone marrow progenitors initiate the pre-metastatic niche. Nature 2005, 438, 820-827. [CrossRef] [PubMed]

113. Lukanidin, E.; Sleeman, J.P. Building the niche: The role of the S100 proteins in metastatic growth. Semin. Cancer Biol. 2012, 22, 216-225. [CrossRef] [PubMed]

114. Colombo, M.; Raposo, G.; Thery, C. Biogenesis, secretion, and intercellular interactions of exosomes and other extracellular vesicles. Annu. Rev. Cell Dev. Biol. 2014, 30, 255-289. [CrossRef] [PubMed]

115. Andaloussi, S.E.; Mäger, I.; Breakefield, X.O.; Wood, M.J. Extracellular vesicles: Biology and emerging therapeutic opportunities. Nat. Rev. Drug Discov. 2013, 12, 347-357. [CrossRef] [PubMed]

116. Hoshino, A.; Costa-Silva, B.; Shen, T.L.; Rodrigues, G.; Hashimoto, A.; Tesic Mark, M.; Molina, H.; Kohsaka, S.; Di Giannatale, A.; Ceder, S.; et al. Tumour exosome integrins determine organotropic metastasis. Nature 2015, 527, 329-335. [CrossRef] [PubMed]

117. Endo, H.; Inoue, M. Dormancy in cancer. Cancer Sci. 2019, 110, 474-480. [CrossRef]

118. Bleau, A.M.; Agliano, A.; Larzabal, L.; de Aberasturi, A.L.; Calvo, A. Metastatic dormancy: A complex network between cancer stem cells and their microenvironment. Histol. Histopathol. 2014, 29, 1499-1510. [CrossRef]

119. Naumov, G.N.; MacDonald, I.C.; Weinmeister, P.M.; Kerkvliet, N.; Nadkarni, K.V.; Wilson, S.M.; Morris, V.L.; Groom, A.C.; Chambers, A.F. Persistence of solitary mammary carcinoma cells in a secondary site: A possible contributor to dormancy. Cancer Res. 2002, 62, 2162-2168.

120. Demicheli, R. Tumour dormancy: Findings and hypotheses from clinical research on breast cancer. Semin. Cancer Biol. 2001, 11, 297-306. [CrossRef]

121. Barkan, D.; Green, J.E.; Chambers, A.F. Extracellular matrix: A gatekeeper in the transition from dormancy to metastatic growth. Eur. J. Cancer 2010, 46, 1181-1188. [CrossRef] [PubMed]

122. Aguirre-Ghiso, J.A.; Liu, D.; Mignatti, A.; Kovalski, K.; Ossowski, L. Urokinase receptor and fibronectin regulate the ERK(MAPK) to p38(MAPK) activity ratios that determine carcinoma cell proliferation or dormancy in vivo. Mol. Biol. Cell 2001, 12, 863-879. [CrossRef] [PubMed]

123. Giancotti, F.G. Mechanisms governing metastatic dormancy and reactivation. Cell 2013, 155, $750-764$. [CrossRef] [PubMed]

124. Aguirre-Ghiso, J.A. How dormant cancer persists and reawakens. Science 2018, 361, 1314-1315. [CrossRef] [PubMed]

125. Wheeler, S.E.; Clark, A.M.; Taylor, D.P.; Young, C.L.; Pillai, V.C.; Stolz, D.B.; Venkataramanan, R.; Lauffenburger, D.; Griffith, L.; Wells, A. Spontaneous dormancy of metastatic breast cancer cells in an all human liver microphysiologic system. Br. J. Cancer 2014, 111, 2342-2350. [CrossRef] [PubMed] 
126. Clark, A.M.; Wheeler, S.E.; Young, C.L.; Stockdale, L.; Shepard Neiman, J.; Zhao, W.; Stolz, D.B.; Venkataramanan, R.; Lauffenburger, D.; Griffith, L.; et al. A liver microphysiological system of tumor cell dormancy and inflammatory responsiveness is affected by scaffold properties. Lab Chip 2016, 17, 156-168. [CrossRef]

127. El Touny, L.H.; Vieira, A.; Mendoza, A.; Khanna, C.; Hoenerhoff, M.J.; Green, J.E. Combined SFK/MEK inhibition prevents metastatic outgrowth of dormant tumor cells. J. Clin. Investig. 2014, 124, 156-168. [CrossRef]

128. Ghajar, C.M. Metastasis prevention by targeting the dormant niche. Nat. Rev. Cancer 2015, 15, $238-247$. [CrossRef]

129. Sriram, R.; Lo, V.; Pryce, B.; Antonova, L.; Mears, A.J.; Daneshmand, M.; McKay, B.; Conway, S.J.; Muller, W.J.; Sabourin, L.A. Loss of periostin/OSF-2 in ErbB2/Neu-driven tumors results in androgen receptor-positive molecular apocrine-like tumors with reduced Notch1 activity. Breast Cancer Res. 2015, 17, 7. [CrossRef]

130. Jo, H.; Jia, Y.; Subramanian, K.K.; Hattori, H.; Luo, H.R. Cancer cell-derived clusterin modulates the phosphatidylinositol 3'-kinase-Akt pathway through attenuation of insulin-like growth factor 1 during serum deprivation. Mol. Cell Biol. 2008, 28, 4285-4299. [CrossRef]

131. Balz, L.M.; Bartkowiak, K.; Andreas, A.; Pantel, K.; Niggemann, B.; Zanker, K.S.; Brandt, B.H.; Dittmar, T. The interplay of HER2/HER3/PI3K and EGFR/HER2/PLC-gamma1 signalling in breast cancer cell migration and dissemination. J. Pathol. 2012, 227, 234-244. [CrossRef] [PubMed]

132. Vera-Ramirez, L.; Vodnala, S.K.; Nini, R.; Hunter, K.W.; Green, J.E. Autophagy promotes the survival of dormant breast cancer cells and metastatic tumour recurrence. Nat. Commun. 2018, 9, 1944. [CrossRef] [PubMed]

133. Lu, Z.; Luo, R.Z.; Lu, Y.; Zhang, X.; Yu, Q.; Khare, S.; Kondo, S.; Kondo, Y.; Yu, Y.; Mills, G.B.; et al. The tumor suppressor gene ARHI regulates autophagy and tumor dormancy in human ovarian cancer cells. J. Clin. Investig. 2008, 118, 3917-3929. [CrossRef] [PubMed]

134. Pontier, S.M.; Muller, W.J. Integrins in breast cancer dormancy. APMIS 2008, 116, 677-684. [CrossRef] [PubMed]

135. Barkan, D.; Chambers, A.F. beta1-integrin: A potential therapeutic target in the battle against cancer recurrence. Clin. Cancer Res. 2011, 17, 7219-7223. [CrossRef] [PubMed]

136. Lorusso, G.; Ruegg, C. New insights into the mechanisms of organ-specific breast cancer metastasis. Semin. Cancer Biol. 2012, 22, 226-233. [CrossRef] [PubMed]

137. Walker, C.; Mojares, E.; Del Rio Hernandez, A. Role of Extracellular Matrix in Development and Cancer Progression. Int. J. Mol. Sci. 2018, 3028. [CrossRef]

138. Baker, A.M.; Cox, T.R.; Bird, D.; Lang, G.; Murray, G.I.; Sun, X.F.; Southall, S.M.; Wilson, J.R.; Erler, J.T. The role of lysyl oxidase in SRC-dependent proliferation and metastasis of colorectal cancer. J. Natl. Cancer Inst. 2011, 103, 407-424. [CrossRef] [PubMed]

139. Levental, K.R.; Yu, H.; Kass, L.; Lakins, J.N.; Egeblad, M.; Erler, J.T.; Fong, S.F.; Csiszar, K.; Giaccia, A.; Weninger, W.; et al. Matrix crosslinking forces tumor progression by enhancing integrin signaling. Cell 2009, 139, 891-906. [CrossRef]

140. Pickup, M.W.; Laklai, H.; Acerbi, I.; Owens, P.; Gorska, A.E.; Chytil, A.; Aakre, M.; Weaver, V.M.; Moses, H.L. Stromally derived lysyl oxidase promotes metastasis of transforming growth factor-beta-deficient mouse mammary carcinomas. Cancer Res. 2013, 73, 5336-5346. [CrossRef]

141. Knuchel, S.; Anderle, P.; Werfelli, P.; Diamantis, E.; Ruegg, C. Fibroblast surface-associated FGF-2 promotes contact-dependent colorectal cancer cell migration and invasion through FGFR-SRC signaling and integrin alphavbeta5-mediated adhesion. Oncotarget 2015, 6, 14300-14317. [CrossRef] [PubMed]

142. Cattin, S.; Ramont, L.; Ruegg, C. Characterization and In Vivo Validation of a Three-Dimensional Multi-Cellular Culture Model to Study Heterotypic Interactions in Colorectal Cancer Cell Growth, Invasion and Metastasis. Front. Bioeng. Biotechnol. 2018, 6, 97. [CrossRef] [PubMed]

143. Mas-Moruno, C.; Rechenmacher, F.; Kessler, H. Cilengitide: The first anti-angiogenic small molecule drug candidate design, synthesis and clinical evaluation. Anticancer Agents Med. Chem. 2010, 10, 753-768. [CrossRef] [PubMed]

144. Monnier, Y.; Farmer, P.; Bieler, G.; Imaizumi, N.; Sengstag, T.; Alghisi, G.C.; Stehle, J.C.; Ciarloni, L.; Andrejevic-Blant, S.; Moeckli, R.; et al. CYR61 and alphaVbeta5 integrin cooperate to promote invasion and metastasis of tumors growing in preirradiated stroma. Cancer Res. 2008, 68, 7323-7331. [CrossRef] [PubMed] 
145. Brooks, P.C.; Montgomery, A.M.; Rosenfeld, M.; Reisfeld, R.A.; Hu, T.; Klier, G.; Cheresh, D.A. Integrin alpha $\mathrm{v}$ beta 3 antagonists promote tumor regression by inducing apoptosis of angiogenic blood vessels. Cell 1994, 79, 1157-1164. [CrossRef]

146. Liu, Z.; Wang, F.; Chen, X. Integrin alpha(v)beta(3)-Targeted Cancer Therapy. Drug Dev. Res. 2008, 69, 329-339. [CrossRef] [PubMed]

147. Bader, B.L.; Rayburn, H.; Crowley, D.; Hynes, R.O. Extensive vasculogenesis, angiogenesis, and organogenesis precede lethality in mice lacking all alpha v integrins. Cell 1998, 95, 507-519. [CrossRef]

148. Hodivala-Dilke, K.M.; McHugh, K.P.; Tsakiris, D.A.; Rayburn, H.; Crowley, D.; Ullman-Cullere, M.; Ross, F.P.; Coller, B.S.; Teitelbaum, S.; Hynes, R.O. Beta3-integrin-deficient mice are a model for Glanzmann thrombasthenia showing placental defects and reduced survival. J. Clin. Investig. 1999, 103, 229-238. [CrossRef] [PubMed]

149. Reynolds, A.R.; Reynolds, L.E.; Nagel, T.E.; Lively, J.C.; Robinson, S.D.; Hicklin, D.J.; Bodary, S.C.; Hodivala-Dilke, K.M. Elevated Flk1 (vascular endothelial growth factor receptor 2) signaling mediates enhanced angiogenesis in beta3-integrin-deficient mice. Cancer Res. 2004, 64, 8643-8650. [CrossRef] [PubMed]

150. Reynolds, L.E.; Wyder, L.; Lively, J.C.; Taverna, D.; Robinson, S.D.; Huang, X.; Sheppard, D.; Hynes, R.O.; Hodivala-Dilke, K.M. Enhanced pathological angiogenesis in mice lacking beta3 integrin or beta3 and beta5 integrins. Nat. Med. 2002, 8, 27-34. [CrossRef] [PubMed]

151. Steri, V.; Ellison, T.S.; Gontarczyk, A.M.; Weilbaecher, K.; Schneider, J.G.; Edwards, D.; Fruttiger, M.; Hodivala-Dilke, K.M.; Robinson, S.D. Acute depletion of endothelial beta3-integrin transiently inhibits tumor growth and angiogenesis in mice. Circ. Res. 2014, 114, 79-91. [CrossRef] [PubMed]

152. Reynolds, A.R.; Hart, I.R.; Watson, A.R.; Welti, J.C.; Silva, R.G.; Robinson, S.D.; Da Violante, G.; Gourlaouen, M.; Salih, M.; Jones, M.C.; et al. Stimulation of tumor growth and angiogenesis by low concentrations of RGD-mimetic integrin inhibitors. Nat. Med. 2009, 15, 392-400. [CrossRef] [PubMed]

153. Alghisi, G.C.; Ponsonnet, L.; Ruegg, C. The integrin antagonist cilengitide activates alphaVbeta3, disrupts VE-cadherin localization at cell junctions and enhances permeability in endothelial cells. PLoS ONE 2009, 4, e4449. [CrossRef] [PubMed]

154. Ten Hagen, T.L.; Seynhaeve, A.L.; de Wiel-Ambagtsheer, G.; de Bruijn, E.A.; van Tiel, S.T.; Ruegg, C.; Meyring, M.; Grell, M.; Goodman, S.L.; Eggermont, A.M. The alphaVbeta3/alphaVbeta5 integrin inhibitor cilengitide augments tumor response to melphalan isolated limb perfusion in a sarcoma model. Int. J. Cancer 2013, 132, 2694-2704. [CrossRef] [PubMed]

155. Ruegg, C.; Yilmaz, A.; Bieler, G.; Bamat, J.; Chaubert, P.; Lejeune, F.J. Evidence for the involvement of endothelial cell integrin alphaVbeta 3 in the disruption of the tumor vasculature induced by TNF and IFN-gamma. Nat. Med. 1998, 4, 408-414. [CrossRef] [PubMed]

156. Bieler, G.; Hasmim, M.; Monnier, Y.; Imaizumi, N.; Ameyar, M.; Bamat, J.; Ponsonnet, L.; Chouaib, S.; Grell, M.; Goodman, S.L.; et al. Distinctive role of integrin-mediated adhesion in TNF-induced PKB/Akt and NF-kappaB activation and endothelial cell survival. Oncogene 2007, 26, 5722-5732. [CrossRef]

157. Dormond, O.; Foletti, A.; Paroz, C.; Ruegg, C. NSAIDs inhibit alpha V beta 3 integrin-mediated and Cdc42/Rac-dependent endothelial-cell spreading, migration and angiogenesis. Nat. Med. 2001, 7, 1041-1047. [CrossRef]

158. Avraamides, C.J.; Garmy-Susini, B.; Varner, J.A. Integrins in angiogenesis and lymphangiogenesis. Nat. Rev. Cancer 2008, 8, 604-617. [CrossRef]

159. Jahangiri, A.; Aghi, M.K.; Carbonell, W.S. beta1 integrin: Critical path to antiangiogenic therapy resistance and beyond. Cancer Res. 2014, 74, 3-7. [CrossRef]

160. Wick, W.; Platten, M.; Wick, A.; Hertenstein, A.; Radbruch, A.; Bendszus, M.; Winkler, F. Current status and future directions of anti-angiogenic therapy for gliomas. Neuro Oncol. 2016, 18, 315-328. [CrossRef]

161. Zarrin, B.; Zarifi, F.; Vaseghi, G.; Javanmard, S.H. Acquired tumor resistance to antiangiogenic therapy: Mechanisms at a glance. J. Res. Med. Sci. 2017, 22, 117. [CrossRef] [PubMed]

162. Bergers, G.; Hanahan, D. Modes of resistance to anti-angiogenic therapy. Nat. Rev. Cancer 2008, 8, $592-603$. [CrossRef] [PubMed]

163. Loges, S.; Schmidt, T.; Carmeliet, P. Mechanisms of resistance to anti-angiogenic therapy and development of third-generation anti-angiogenic drug candidates. Genes Cancer 2010, 1, 12-25. [CrossRef] [PubMed] 
164. Kapp, T.G.; Rechenmacher, F.; Sobahi, T.R.; Kessler, H. Integrin modulators: A patent review. Expert Opin. Pat. 2013, 23, 1273-1295. [CrossRef] [PubMed]

165. Hersey, P.; Sosman, J.; O’Day, S.; Richards, J.; Bedikian, A.; Gonzalez, R.; Sharfman, W.; Weber, R.; Logan, T.; Buzoianu, M.; et al. A randomized phase 2 study of etaracizumab, a monoclonal antibody against integrin alpha(v)beta(3), + or - dacarbazine in patients with stage IV metastatic melanoma. Cancer 2010, 116, 1526-1534. [CrossRef] [PubMed]

166. Moschos, S.J.; Sander, C.A.; Wang, W.; Reppert, S.L.; Drogowski, L.M.; Jukic, D.M.; Rao, U.N.; Athanassiou, C.; Buzoianu, M.; Mandic, M.; et al. Pharmacodynamic (phase 0) study using etaracizumab in advanced melanoma. J. Immunother. 2010, 33, 316-325. [CrossRef] [PubMed]

167. Wirth, M.; Heidenreich, A.; Gschwend, J.E.; Gil, T.; Zastrow, S.; Laniado, M.; Gerloff, J.; Zuhlsdorf, M.; Mordenti, G.; Uhl, W.; et al. A multicenter phase 1 study of EMD 525797 (DI17E6), a novel humanized monoclonal antibody targeting alphav integrins, in progressive castration-resistant prostate cancer with bone metastases after chemotherapy. Eur. Urol. 2014, 65, 897-904. [CrossRef]

168. O’Day, S.J.; Pavlick, A.C.; Albertini, M.R.; Hamid, O.; Schalch, H.; Lang, Z.; Ling, J.; Mata, M.; Reddy, M.; Foster, B. Clinical and pharmacologic evaluation of two dose levels of intetumumab (CNTO 95) in patients with melanoma or angiosarcoma. Investig. New Drugs 2012, 30, 1074-1081. [CrossRef]

169. Hussain, M.; Le Moulec, S.; Gimmi, C.; Bruns, R.; Straub, J.; Miller, K.; Group, P.S. Differential Effect on Bone Lesions of Targeting Integrins: Randomized Phase II Trial of Abituzumab in Patients with Metastatic Castration-Resistant Prostate Cancer. Clin. Cancer Res. 2016, 22, 3192-3200. [CrossRef]

170. Almokadem, S.; Belani, C.P. Volociximab in cancer. Expert Opin. Biol. 2012, 12, 251-257. [CrossRef]

171. Bell-McGuinn, K.M.; Matthews, C.M.; Ho, S.N.; Barve, M.; Gilbert, L.; Penson, R.T.; Lengyel, E.; Palaparthy, R.; Gilder, K.; Vassos, A.; et al. A phase II, single-arm study of the anti-alpha5beta1 integrin antibody volociximab as monotherapy in patients with platinum-resistant advanced epithelial ovarian or primary peritoneal cancer. Gynecol. Oncol. 2011, 121, 273-279. [CrossRef] [PubMed]

172. Besse, B.; Tsao, L.C.; Chao, D.T.; Fang, Y.; Soria, J.C.; Almokadem, S.; Belani, C.P. Phase Ib safety and pharmacokinetic study of volociximab, an anti-alpha5beta1 integrin antibody, in combination with carboplatin and paclitaxel in advanced non-small-cell lung cancer. Ann. Oncol. 2013, 24, 90-96. [CrossRef] [PubMed]

173. Shi, Y.; Sun, Y. Medical management of lung cancer: Experience in China. Thorac. Cancer 2015, 6, 10-16. [CrossRef] [PubMed]

174. Zhong, Z.; Gu, X.; Zhang, Z.; Wang, D.; Qing, Y.; Li, M.; Dai, N. Recombinant human endostatin combined with definitive chemoradiotherapy as primary treatment for patients with unresectable but without systemic metastatic squamous cell carcinoma of the oesophagus. Br. J. Radiol. 2012, 85, e1104-e1109. [CrossRef] [PubMed]

175. Mohajeri, A.; Sanaei, S.; Kiafar, F.; Fattahi, A.; Khalili, M.; Zarghami, N. The Challenges of Recombinant Endostatin in Clinical Application: Focus on the Different Expression Systems and Molecular Bioengineering. Adv. Pharm. Bull. 2017, 7, 21-34. [CrossRef] [PubMed]

176. Stupp, R.; Ruegg, C. Integrin inhibitors reaching the clinic. J. Clin. Oncol. 2007, 25, 1637-1638. [CrossRef] [PubMed]

177. Weller, M.; Nabors, L.B.; Gorlia, T.; Leske, H.; Rushing, E.; Bady, P.; Hicking, C.; Perry, J.; Hong, Y.K.; Roth, P.; et al. Cilengitide in newly diagnosed glioblastoma: Biomarker expression and outcome. Oncotarget 2016, 7, 15018-15032. [CrossRef]

178. Su, J.; Cai, M.; Li, W.; Hou, B.; He, H.; Ling, C.; Huang, T.; Liu, H.; Guo, Y. Molecularly Targeted Drugs Plus Radiotherapy and Temozolomide Treatment for Newly Diagnosed Glioblastoma: A Meta-Analysis and Systematic Review. Oncol. Res. 2016, 24, 117-128. [CrossRef]

179. Cianfrocca, M.E.; Kimmel, K.A.; Gallo, J.; Cardoso, T.; Brown, M.M.; Hudes, G.; Lewis, N.; Weiner, L.; Lam, G.N.; Brown, S.C.; et al. Phase 1 trial of the antiangiogenic peptide ATN-161 (Ac-PHSCN-NH(2)), a beta integrin antagonist, in patients with solid tumours. Br. J. Cancer 2006, 94, 1621-1626. [CrossRef]

180. Khalili, P.; Arakelian, A.; Chen, G.; Plunkett, M.L.; Beck, I.; Parry, G.C.; Donate, F.; Shaw, D.E.; Mazar, A.P.; Rabbani, S.A. A non-RGD-based integrin binding peptide (ATN-161) blocks breast cancer growth and metastasis in vivo. Mol. Cancer 2006, 5, 2271-2280. [CrossRef] 
181. Stoeltzing, O.; Liu, W.; Reinmuth, N.; Fan, F.; Parry, G.C.; Parikh, A.A.; McCarty, M.F.; Bucana, C.D.; Mazar, A.P.; Ellis, L.M. Inhibition of integrin alpha5beta1 function with a small peptide (ATN-161) plus continuous 5-FU infusion reduces colorectal liver metastases and improves survival in mice. Int. J. Cancer 2003, 104, 496-503. [CrossRef] [PubMed]

182. Wang, W.Q.; Wang, F.H.; Qin, W.X.; Liu, H.Y.; Lu, B.; Chung, C.; Zhu, J.; Gu, Q.; Shi, W.; Wen, C.; et al. Joint Antiangiogenic Effect of ATN-161 and Anti-VEGF Antibody in a Rat Model of Early Wet Age-Related Macular Degeneration. Mol. Pharm. 2016, 13, 2881-2890. [CrossRef] [PubMed]

183. Marelli, U.K.; Rechenmacher, F.; Sobahi, T.R.; Mas-Moruno, C.; Kessler, H. Tumor Targeting via Integrin Ligands. Front. Oncol. 2013, 3, 222. [CrossRef] [PubMed]

184. Cheng, Y.; Ji, Y. RGD-modified polymer and liposome nanovehicles: Recent research progress for drug delivery in cancer therapeutics. Eur. J. Pharm. Sci. 2019, 128, 8-17. [CrossRef] [PubMed]

185. Gajbhiye, K.R.; Gajbhiye, V.; Siddiqui, I.A.; Gajbhiye, J.M. cRGD functionalised nanocarriers for targeted delivery of bioactives. J. Drug Target. 2018, 1-14. [CrossRef] [PubMed]

186. Danhier, F.; Le Breton, A.; Preat, V. RGD-based strategies to target alpha(v) beta(3) integrin in cancer therapy and diagnosis. Mol. Pharm. 2012, 9, 2961-2973. [CrossRef] [PubMed]

187. Lu, L.; Qi, H.; Zhu, J.; Sun, W.X.; Zhang, B.; Tang, C.Y.; Cheng, Q. Vascular-homing peptides for cancer therapy. Biomed. Pharm. 2017, 92, 187-195. [CrossRef]

188. Fu, S.; Xu, X.; Ma, Y.; Zhang, S.; Zhang, S. RGD peptide-based non-viral gene delivery vectors targeting integrin alphavbeta3 for cancer therapy. J. Drug Target. 2019, 27, 1-11. [CrossRef] [PubMed]

189. Arosio, D.; Casagrande, C. Advancement in integrin facilitated drug delivery. Adv. Drug Deliv. Rev. 2016, 97, 111-143. [CrossRef]

190. Arosio, D.; Manzoni, L.; Corno, C.; Perego, P. Integrin-Targeted Peptide- and Peptidomimetic-Drug Conjugates for the Treatment of Tumors. Recent Pat. Anticancer Drug Discov. 2017, 12, 148-168. [CrossRef]

191. Doolittle, E.; Peiris, P.M.; Doron, G.; Goldberg, A.; Tucci, S.; Rao, S.; Shah, S.; Sylvestre, M.; Govender, P.; Turan, O.; et al. Spatiotemporal Targeting of a Dual-Ligand Nanoparticle to Cancer Metastasis. ACS Nano 2015, 9, 8012-8021. [CrossRef] [PubMed]

192. Shi, S.; Zhou, M.; Li, X.; Hu, M.; Li, C.; Li, M.; Sheng, F.; Li, Z.; Wu, G.; Luo, M.; et al. Synergistic active targeting of dually integrin alphavbeta3/CD44-targeted nanoparticles to B16F10 tumors located at different sites of mouse bodies. J. Control. Release 2016, 235, 1-13. [CrossRef] [PubMed]

193. Peiris, P.M.; He, F.; Covarrubias, G.; Raghunathan, S.; Turan, O.; Lorkowski, M.; Gnanasambandam, B.; Wu, C.; Schiemann, W.P.; Karathanasis, E. Precise targeting of cancer metastasis using multi-ligand nanoparticles incorporating four different ligands. Nanoscale 2018, 10, 6861-6871. [CrossRef] [PubMed]

194. Ruoslahti, E. Tumor penetrating peptides for improved drug delivery. Adv. Drug Deliv. Rev. 2017, 110-111, 3-12. [CrossRef] [PubMed]

195. Sangnier, A.P.; Preveral, S.; Curcio, A.; Silva, A.K.; Lefèvre, C.T.; Pignol, D.; Lalatonne, Y.; Wilhelm, C. Targeted thermal therapy with genetically engineered magnetite magnetosomes@RGD: Photothermia is far more efficient than magnetic hyperthermia. J. Control. Release 2018, 279, 271-281. [CrossRef] [PubMed]

196. Liu, Z.; Wang, F. Development of RGD-based radiotracers for tumor imaging and therapy: Translating from bench to bedside. Curr. Mol. Med. 2013, 13, 1487-1505. [CrossRef] [PubMed]

197. Moral, M.E.G.; Siahaan, T.J. Conjugates of Cell Adhesion Peptides for Therapeutics and Diagnostics Against Cancer and Autoimmune Diseases. Curr. Top. Med. Chem. 2017, 17, 3425-3443. [CrossRef] [PubMed]

198. Debordeaux, F.; Chansel-Debordeaux, L.; Pinaquy, J.B.; Fernandez, P.; Schulz, J. What about alphavbeta3 integrins in molecular imaging in oncology? Nucl. Med. Biol. 2018, 62-63, 31-46. [CrossRef]

199. Beer, A.J.; Haubner, R.; Sarbia, M.; Goebel, M.; Luderschmidt, S.; Grosu, A.L.; Schnell, O.; Niemeyer, M.; Kessler, H.; Wester, H.J.; et al. Positron emission tomography using [18F]Galacto-RGD identifies the level of integrin alpha(v)beta3 expression in man. Clin. Cancer Res. 2006, 12, 3942-3949. [CrossRef]

200. Chen, H.; Niu, G.; Wu, H.; Chen, X. Clinical Application of Radiolabeled RGD Peptides for PET Imaging of Integrin alphavbeta3. Theranostics 2016, 6, 78-92. [CrossRef]

201. Cai, W.; Wu, Y.; Chen, K.; Cao, Q.; Tice, D.A.; Chen, X. In vitro and in vivo characterization of 64Cu-labeled Abegrin, a humanized monoclonal antibody against integrin alpha v beta 3. Cancer Res 2006, 66, 9673-9681. [CrossRef] [PubMed] 
202. Buchegger, F.; Viertl, D.; Baechler, S.; Dunet, V.; Kosinski, M.; Poitry-Yamate, C.; Ruegg, C.; Prior, J.O. 68Ga-NODAGA-RGDyK for alphavbeta3 integrin PET imaging. Preclinical investigation and dosimetry. Nuklearmedizin 2011, 50, 225-233. [CrossRef] [PubMed]

203. Decristoforo, C.; Faintuch-Linkowski, B.; Rey, A.; von Guggenberg, E.; Rupprich, M.; Hernandez-Gonzales, I.; Rodrigo, T.; Haubner, R. [99mTc]HYNIC-RGD for imaging integrin alphavbeta3 expression. Nucl. Med. Biol. 2006, 33, 945-952. [CrossRef] [PubMed]

204. Liu, S.; Hsieh, W.Y.; Jiang, Y.; Kim, Y.S.; Sreerama, S.G.; Chen, X.; Jia, B.; Wang, F. Evaluation of a $(99 \mathrm{~m}) \mathrm{Tc}$-labeled cyclic RGD tetramer for noninvasive imaging integrin alpha(v)beta3-positive breast cancer. Bioconjug. Chem. 2007, 18, 438-446. [CrossRef] [PubMed]

205. Hsu, A.R.; Hou, L.C.; Veeravagu, A.; Greve, J.M.; Vogel, H.; Tse, V.; Chen, X. In vivo near-infrared fluorescence imaging of integrin alphavbeta3 in an orthotopic glioblastoma model. Mol. Imaging Biol. 2006, 8, 315-323. [CrossRef] [PubMed]

206. Atkinson, S.J.; Ellison, T.S.; Steri, V.; Gould, E.; Robinson, S.D. Redefining the role(s) of endothelial alphavbeta3-integrin in angiogenesis. Biochem. Soc. Trans. 2014, 42, 1590-1595. [CrossRef]

207. Zhao, H.; Gao, H.; Zhai, L.; Liu, X.; Jia, B.; Shi, J.; Wang, F. (99m)Tc-HisoDGR as a Potential SPECT Probe for Orthotopic Glioma Detection via Targeting of Integrin alpha5beta1. Bioconjug. Chem. 2016, 27, 1259-1266. [CrossRef]

208. Haubner, R.; Maschauer, S.; Einsiedel, J.; Eder, I.E.; Rangger, C.; Gmeiner, P.; Virgolini, I.J.; Prante, O. H-CRRETAWAC-OH, a lead structure for the development of radiotracer targeting integrin alpha5beta1? Biomed. Res. Int. 2014, 2014, 243185. [CrossRef]

209. D'Alessandria, C.; Pohle, K.; Rechenmacher, F.; Neubauer, S.; Notni, J.; Wester, H.J.; Schwaiger, M.; Kessler, H.; Beer, A.J. In vivo biokinetic and metabolic characterization of the (6)(8)Ga-labelled alpha5beta1-selective peptidomimetic FR366. Eur. J. Nucl. Med. Mol. Imaging 2016, 43, 953-963. [CrossRef]

210. Altmann, A.; Sauter, M.; Roesch, S.; Mier, W.; Warta, R.; Debus, J.; Dyckhoff, G.; Herold-Mende, C.; Haberkorn, U. Identification of a Novel ITGalphavbeta6-Binding Peptide Using Protein Separation and Phage Display. Clin. Cancer Res. 2017, 23, 4170-4180. [CrossRef]

211. Maltsev, O.V.; Marelli, U.K.; Kapp, T.G.; Di Leva, F.S.; Di Maro, S.; Nieberler, M.; Reuning, U.; Schwaiger, M.; Novellino, E.; Marinelli, L.; et al. Stable Peptides Instead of Stapled Peptides: Highly Potent alphavbeta6-Selective Integrin Ligands. Angew. Chem. Int. Ed. Engl. 2016, 55, 1535-1539. [CrossRef] [PubMed]

212. Nieberler, M.; Reuning, U.; Kessler, H.; Reichart, F.; Weirich, G.; Wolff, K.D. Fluorescence imaging of invasive head and neck carcinoma cells with integrin alphavbeta6-targeting RGD-peptides: An approach to a fluorescence-assisted intraoperative cytological assessment of bony resection margins. Br. J. Oral Maxillofac. Surg. 2018, 56, 972-978. [CrossRef]

213. Elez, E.; Kocakova, I.; Hohler, T.; Martens, U.M.; Bokemeyer, C.; Van Cutsem, E.; Melichar, B.; Smakal, M.; Csoszi, T.; Topuzov, E.; et al. Abituzumab combined with cetuximab plus irinotecan versus cetuximab plus irinotecan alone for patients with KRAS wild-type metastatic colorectal cancer: The randomised phase I/II POSEIDON trial. Ann. Oncol. 2015, 26, 132-140. [CrossRef]

214. O’Day, S.; Pavlick, A.; Loquai, C.; Lawson, D.; Gutzmer, R.; Richards, J.; Schadendorf, D.; Thompson, J.A.; Gonzalez, R.; Trefzer, U.; et al. A randomised, phase II study of intetumumab, an anti-alphav-integrin mAb, alone and with dacarbazine in stage IV melanoma. Br. J. Cancer 2011, 105, 346-352. [CrossRef] [PubMed]

215. Heidenreich, A.; Rawal, S.K.; Szkarlat, K.; Bogdanova, N.; Dirix, L.; Stenzl, A.; Welslau, M.; Wang, G.; Dawkins, F.; de Boer, C.J.; et al. A randomized, double-blind, multicenter, phase 2 study of a human monoclonal antibody to human alphanu integrins (intetumumab) in combination with docetaxel and prednisone for the first-line treatment of patients with metastatic castration-resistant prostate cancer. Ann. Oncol. 2013, 24, 329-336. [CrossRef]

216. Vermorken, J.B.; Peyrade, F.; Krauss, J.; Mesia, R.; Remenar, E.; Gauler, T.C.; Keilholz, U.; Delord, J.P.; Schafhausen, P.; Erfan, J.; et al. Cisplatin, 5-fluorouracil, and cetuximab (PFE) with or without cilengitide in recurrent/metastatic squamous cell carcinoma of the head and neck: Results of the randomized phase I/II ADVANTAGE trial (phase II part). Ann. Oncol. 2014, 25, 682-688. [CrossRef] [PubMed] 
217. Vansteenkiste, J.; Barlesi, F.; Waller, C.F.; Bennouna, J.; Gridelli, C.; Goekkurt, E.; Verhoeven, D.; Szczesna, A.; Feurer, M.; Milanowski, J.; et al. Cilengitide combined with cetuximab and platinum-based chemotherapy as first-line treatment in advanced non-small-cell lung cancer (NSCLC) patients: Results of an open-label, randomized, controlled phase II study (CERTO). Ann. Oncol. 2015, 26, 1734-1740. [CrossRef]

218. Nabors, L.B.; Mikkelsen, T.; Hegi, M.E.; Ye, X.; Batchelor, T.; Lesser, G.; Peereboom, D.; Rosenfeld, M.R.; Olsen, J.; Brem, S.; et al. A safety run-in and randomized phase 2 study of cilengitide combined with chemoradiation for newly diagnosed glioblastoma (NABTT 0306). Cancer 2012, 118, 5601-5607. [CrossRef]

219. Reardon, D.A.; Fink, K.L.; Mikkelsen, T.; Cloughesy, T.F.; O’Neill, A.; Plotkin, S.; Glantz, M.; Ravin, P.; Raizer, J.J.; Rich, K.M.; et al. Randomized phase II study of cilengitide, an integrin-targeting arginineglycine-aspartic acid peptide, in recurrent glioblastoma multiforme. J. Clin. Oncol. 2008, 26, 5610-5617. [CrossRef]

220. Alva, A.; Slovin, S.; Daignault, S.; Carducci, M.; Dipaola, R.; Pienta, K.; Agus, D.; Cooney, K.; Chen, A.; Smith, D.C.; et al. Phase II study of cilengitide (EMD 121974, NSC 707544) in patients with non-metastatic castration resistant prostate cancer, NCI-6735. A study by the DOD/PCF prostate cancer clinical trials consortium. Investig. New Drugs 2012, 30, 749-757. [CrossRef]

221. Stupp, R.; Hegi, M.E.; Neyns, B.; Goldbrunner, R.; Schlegel, U.; Clement, P.M.; Grabenbauer, G.G.; Ochsenbein, A.F.; Simon, M.; Dietrich, P.Y.; et al. Phase I/IIa study of cilengitide and temozolomide with concomitant radiotherapy followed by cilengitide and temozolomide maintenance therapy in patients with newly diagnosed glioblastoma. J. Clin. Oncol. 2010, 28, 2712-2718. [CrossRef] [PubMed]

222. Nabors, L.B.; Fink, K.L.; Mikkelsen, T.; Grujicic, D.; Tarnawski, R.; Nam, D.H.; Mazurkiewicz, M.; Salacz, M.; Ashby, L.; Zagonel, V.; et al. Two cilengitide regimens in combination with standard treatment for patients with newly diagnosed glioblastoma and unmethylated MGMT gene promoter: Results of the open-label, controlled, randomized phase II CORE study. Neuro-oncology 2015, 17, 708-717. [CrossRef] [PubMed]

223. Jin, H.; Varner, J. Integrins: Roles in cancer development and as treatment targets. Br. J. Cancer 2004, 90, 561-565. [CrossRef] [PubMed]

224. Tucker, G.C. Integrins: Molecular targets in cancer therapy. Curr. Oncol. Rep. 2006, 8, 96-103. [CrossRef] [PubMed]

225. Tucker, G.C. Inhibitors of integrins. Curr. Opin. Pharm. 2002, 2, 394-402. [CrossRef]

226. Tolomelli, A.; Galletti, P.; Baiula, M.; Giacomini, D. Can Integrin Agonists Have Cards to Play against Cancer? A Literature Survey of Small Molecules Integrin Activators. Cancers 2017, 78. [CrossRef]

227. Legler, D.F.; Wiedle, G.; Ross, F.P.; Imhof, B.A. Superactivation of integrin alphavbeta3 by low antagonist concentrations. J. Cell Sci. 2001, 114, 1545-1553. [PubMed]

228. Mould, A.P.; Craig, S.E.; Byron, S.K.; Humphries, M.J.; Jowitt, T.A. Disruption of integrin-fibronectin complexes by allosteric but not ligand-mimetic inhibitors. Biochem. J. 2014, 464, 301-313. [CrossRef]

229. Travis, M.A.; Humphries, J.D.; Humphries, M.J. An unraveling tale of how integrins are activated from within. Trends Pharmacol. Sci. 2003, 24, 192-197. [CrossRef]

230. Oguey, D.; George, P.; Ruegg, C. Disruption of integrin-dependent adhesion and survival of endothelial cells by recombinant adenovirus expressing isolated beta integrin cytoplasmic domains. Gene Ther. 2000, 7 , 1292-1303. [CrossRef]

231. Hasmim, M.; Vassalli, G.; Alghisi, G.; Bamat, J.; Ponsonnet, L.; Bieler, G.; Bonnard, C.; Paroz, C.; Oguey, D.; Rüegg, C. Expressed isolated integrin b1 subunit cytodomain induces endothelial cell death secondary to detachment. Thromb. Haemost. 2005, 94, 1060-1070. [PubMed]

232. Foletti, A.; Alghisi, G.; Ponsonnet, L.; Ruegg, C. Isolated integrin beta3 subunit cytoplasmic domains require membrane anchorage and the NPXY motif to recruit to adhesion complexes but do not discriminate between beta1- and beta3-positive complexes. Thromb. Haemost. 2005, 94, 155-166. [PubMed]

233. Mahabeleshwar, G.H.; Feng, W.; Phillips, D.R.; Byzova, T.V. Integrin signaling is critical for pathological angiogenesis. J. Exp. Med. 2006, 203, 2495-2507. [CrossRef] [PubMed]

234. Vouret-Craviari, V.; Boulter, E.; Grall, D.; Matthews, C.; Van Obberghen-Schilling, E. ILK is required for the assembly of matrix-forming adhesions and capillary morphogenesis in endothelial cells. J. Cell Sci. 2004, 117, 4559-4569. [CrossRef] [PubMed] 
235. Calderwood, D.A.; Fujioka, Y.; de Pereda, J.M.; Garcia-Alvarez, B.; Nakamoto, T.; Margolis, B.; McGlade, C.J.; Liddington, R.C.; Ginsberg, M.H. Integrin beta cytoplasmic domain interactions with phosphotyrosine-binding domains: A structural prototype for diversity in integrin signaling. Proc. Natl. Acad. Sci. USA 2003, 100, 2272-2277. [CrossRef] [PubMed]

236. Liao, Z.; Kato, H.; Pandey, M.; Cantor, J.M.; Ablooglu, A.J.; Ginsberg, M.H.; Shattil, S.J. Interaction of kindlin-2 with integrin beta 3 promotes outside-in signaling responses by the alphaVbeta3 vitronectin receptor. Blood 2015, 125, 1995-2004. [CrossRef]

237. Weis, S.M.; Cheresh, D.A. Tumor angiogenesis: Molecular pathways and therapeutic targets. Nat. Med. 2011, 17, 1359-1370. [CrossRef]

238. Carmeliet, P.; Jain, R.K. Molecular mechanisms and clinical applications of angiogenesis. Nature 2011, 473, 298-307. [CrossRef]

239. Evans, C.W. Cell adhesion and metastasis. Cell Biol. Int. Rep. 1992, 16, 1-10. [CrossRef]

240. Hanahan, D.; Weinberg, R.A. Hallmarks of cancer: The next generation. Cell 2011, 144, 646-674. [CrossRef]

241. Gundem, G.; Van Loo, P.; Kremeyer, B.; Alexandrov, L.B.; Tubio, J.M.C.; Papaemmanuil, E.; Brewer, D.S.; Kallio, H.M.L.; Hognas, G.; Annala, M.; et al. The evolutionary history of lethal metastatic prostate cancer. Nature 2015, 520, 353-357. [CrossRef] [PubMed]

242. Kim, M.Y.; Oskarsson, T.; Acharyya, S.; Nguyen, D.X.; Zhang, X.H.; Norton, L.; Massague, J. Tumor self-seeding by circulating cancer cells. Cell 2009, 139, 1315-1326. [CrossRef] [PubMed]

243. Lorusso, G.; Ruegg, C. The tumor microenvironment and its contribution to tumor evolution toward metastasis. Histochem. Cell Biol. 2008, 130, 1091-1103. [CrossRef] [PubMed]

244. Fujiwara, H.; Hamaoka, T. Coordination of chemokine and adhesion systems in intratumoral $\mathrm{T}$ cell migration responsible for the induction of tumor regression. Int. Immunopharmacol. 2001, 1, 613-623. [CrossRef]

245. Ager, A.; Watson, H.A.; Wehenkel, S.C.; Mohammed, R.N. Homing to solid cancers: A vascular checkpoint in adoptive cell therapy using CAR T-cells. Biochem. Soc. Trans. 2016, 44, 377-385. [CrossRef] [PubMed]

246. Mellman, I.; Coukos, G.; Dranoff, G. Cancer immunotherapy comes of age. Nature 2011, 480, 480-489. [CrossRef]

247. Jin, H.; Su, J.; Garmy-Susini, B.; Kleeman, J.; Varner, J. Integrin alpha4beta1 promotes monocyte trafficking and angiogenesis in tumors. Cancer Res. 2006, 66, 2146-2152. [CrossRef] [PubMed]

248. Kerbel, R.S.; Guerin, E.; Francia, G.; Xu, P.; Lee, C.R.; Ebos, J.M.; Man, S. Preclinical recapitulation of antiangiogenic drug clinical efficacies using models of early or late stage breast cancer metastatis. Breast 2013, 22 (Suppl. 2), S57-S65. [CrossRef]

249. Gengenbacher, N.; Singhal, M.; Augustin, H.G. Preclinical mouse solid tumour models: Status quo, challenges and perspectives. Nat. Rev. Cancer 2017, 17, 751-765. [CrossRef] 